Marquette University

e-Publications@Marquette

7-17-2009

\title{
Polymer Nanocomposites Using Zinc Aluminum and Magnesium Aluminum Oleate Layered Double Hydroxides: Effects of LDH Divalent Metals on Dispersion, Thermal, Mechanical and Fire Performance in Various Polymers
}

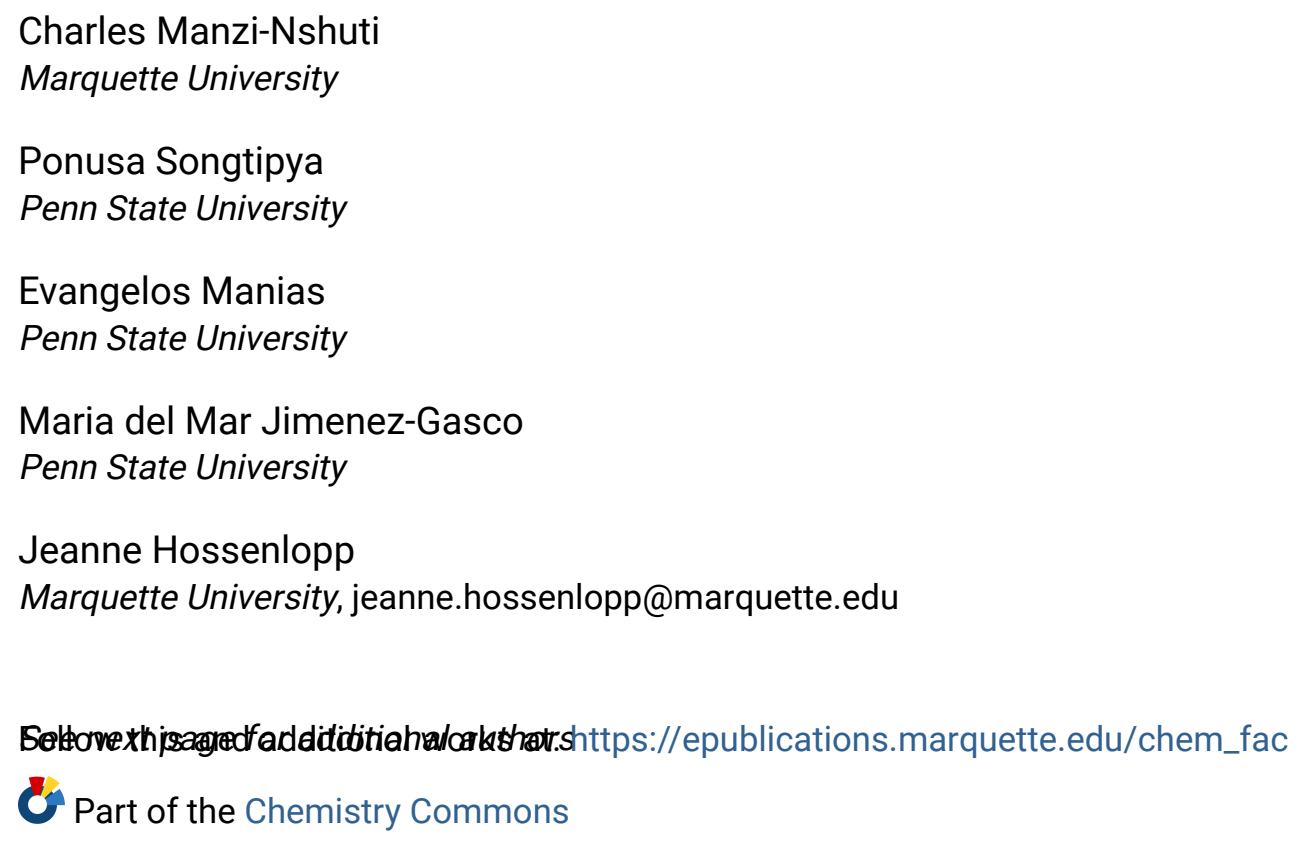




\section{Authors}

Charles Manzi-Nshuti, Ponusa Songtipya, Evangelos Manias, Maria del Mar Jimenez-Gasco, Jeanne Hossenlopp, and Charles Wilkie 


\title{
Polymer nanocomposites using zinc aluminum and magnesium aluminum oleate layered double hydroxides: Effects of LDH divalent metals on dispersion, thermal, mechanical and fire performance in various polymers
}

\author{
Charles Manzi-Nshuti \\ Department of Chemistry and Fire Retardant Research Facility, \\ Marquette University \\ Milwaukee, WI \\ Ponusa Songtipya \\ Department of Materials Science and Engineering, Penn State \\ University \\ University Park, $P A$ \\ Plant Pathology Department, Penn State University \\ University Park, PA \\ E. Manias \\ Department of Materials Science and Engineering, Penn State \\ University \\ University Park, PA
}

Polymer, Vol. 50, No. 15 (July 2009): pg. 3564-3574. DOI. This article is @ Elsevier and permission has been granted for this version to appear in e-Publications@Marquette. Elsevier does not grant permission for this article to be further copied/distributed or hosted elsewhere without the express permission from Elsevier. 


\author{
Maria M. Jimenez-Gasco \\ Plant Pathology Department, Penn State University \\ University Park, $P A$ \\ Jeanne M. Hossenlopp \\ Department of Chemistry and Fire Retardant Research Facility, \\ Marquette University \\ Milwaukee, WI \\ Charles A. Wilkie \\ Department of Chemistry and Fire Retardant Research Facility, \\ Marquette University \\ Milwaukee, WI
}

\begin{abstract}
:
Oleate-containing layered double hydroxides of zinc aluminum ( $\mathrm{ZnAl}$ ) and magnesium aluminum (MgAl) were used to prepare nanocomposites of polyethylene, poly(ethylene-co-butyl acrylate) and poly(methyl methacrylate). The additives and/or their polymer composites were characterized by X-ray diffraction, FTIR, elemental analysis, thermogravimetric analysis, mechanical testing, and cone calorimetry. The unusual packing of the monounsaturated oleate anions in the gallery of these LDHs facilitates the dispersion of these nanomaterials. The inorganic LDH protects the polymer from thermal oxidation, shown by enhancement of the thermal and fire properties of the corresponding polymer nanocomposites. There is a qualitative difference in the morphology of the two LDHs in PE and PMMA. ZnAl is better dispersed in PE while MgAl is better dispersed in PMMA. The zinc-containing material led to a large reduction in the peak heat release rate in polyethylene, while the magnesium-containing material led to enhancement of the fire properties of the more polar poly(methyl methacrylate). These fire properties are consistent with the morphological differences. Neither of these LDHs shows efficacy with poly(ethylene-co-butyl acrylate), which indicates a selective interaction between the LDH and the various polymers.
\end{abstract}

Keywords: Nanocomposites, Layered double hydroxides, Thermal stability.

Polymer, Vol. 50, No. 15 (July 2009): pg. 3564-3574. DOI. This article is (C Elsevier and permission has been granted for this version to appear in e-Publications@Marquette. Elsevier does not grant permission for this article to be further copied/distributed or hosted elsewhere without the express permission from Elsevier. 
NOT THE PUBLISHED VERSION; this is the author's final, peer-reviewed manuscript. The published version may be accessed by following the link in the citation at the bottom of the page.

\section{Introduction}

The fact that appropriately modified clays, natural or synthetic, can disperse in polymer has long been known [1], 1a and 1b. However the polymer/clay interactions as a research field revived after pioneering work on polyamide-6/montmorillonite systems revealed the formation of nanocomposites with enhanced mechanical, thermal, and flammability properties [2] and has since gained large momentum, especially after a subsequent discovery that it is possible to melt-mix polymers with clays without the use of organic solvents [3]. The latter process involves annealing a mixture of polymer and layered silicate powder above the glass transition temperature or melting point of the polymer [3] resulting in composite morphologies that are comparable with solvent-assisted dispersions [4]. Since then, studies on numerous polymer/clay composite systems [5], 5a, 5b, 5c, [6], 6a, 6b, 6c, 6d, [7], 7a and 7b have traced the high thermomechanical reinforcements, such as large enhancements in heat deflection temperature, tensile modulus and elongation at break, to the nanoscale filler dispersion [5] and the strength of the filler/polymer interfaces [6]. These nanocomposite studies primarily focused on cationic layered silicates, while the anionic layered double hydroxides (LDH) have been much less studied [8], 8a and 8b.

Compared to cationic clays, LDHs have similar geometries high aspect ratio nanometer-thin layered platelet particulates - and many of their properties parallel to those of the cationic layered silicate clays, but due to the highly tunable properties of LDH precursors they also offer a number of different functionalities [9], 9a, $9 b$ and 9c. LDHs are of interest to the field of polymer/inorganic nanocomposites, since they may present new opportunities to complement or replace cationic clays; the use of LDHs as stabilizing agents for PVC [10] or stabilizing agents for pigments in polymers [11] for example has been reported. Also, these synthetic anionic clays are also emerging as potential fire retardant additives [12], 12a and 12b. The main challenges to success involve the nanoparticle design, preparation, and full dispersion into polymeric matrices [13].

The LDH structure is described with the ideal formula [ $\mathrm{M}_{1-x}{ }^{\mathrm{II}}$ $\left.\mathrm{M}_{x} \mathrm{III}(\mathrm{OH})_{2}\right]_{\text {intra }}\left[\mathrm{A}_{x / m}{ }^{m-} \cdot n \mathrm{H}_{2} \mathrm{O}\right]_{\text {inter, }}$ where intra and inter denote the intralayer crystalline domain and the interlayer space, respectively; $\mathrm{M}^{\mathrm{II}}$

Polymer, Vol. 50, No. 15 (July 2009): pg. 3564-3574. DOI. This article is (C Elsevier and permission has been granted for this version to appear in e-Publications@Marquette. Elsevier does not grant permission for this article to be further copied/distributed or hosted elsewhere without the express permission from Elsevier. 
is a divalent cation, such as $\mathrm{Mg}, \mathrm{Co}, \mathrm{Ni}, \mathrm{Cu}$, or $\mathrm{Zn}$; $\mathrm{M}^{\mathrm{III}}$ is a trivalent cation, such as $\mathrm{Al}, \mathrm{Cr}, \mathrm{Fe}, \mathrm{V}$, or $\mathrm{Ga}$; charge neutrality is achieved by $x / m$ number of $\mathrm{A}^{m-} m$-valent anions, such as $\mathrm{NO}_{3}{ }^{-}, \mathrm{CO}_{3}{ }^{2-}, \mathrm{Cl}^{-}, \mathrm{SO}_{4}{ }^{2-}$, $\mathrm{C}_{12} \mathrm{H}_{25} \mathrm{SO}_{4}{ }^{-}$, etc, which exist hydrated in the interlayer spacing. $\mathrm{LDHs}$ typically have higher charge density, and thus stronger interaction among the hydroxide sheets, than layered silicates, which makes the exfoliation of LDHs more challenging [14], 14a and 14b. In addition, the basal spacing of pristine LDHs, such as hydrotalcite, is about $0.8 \mathrm{~nm}$ and its layer thickness is about $0.5 \mathrm{~nm}$, so the gallery height is only about $0.3 \mathrm{~nm}$, which is smaller than the monomer diameter of most polymers. Moreover, the hydrophobic character of polymers also hinders the insertion of polymer chains into the LDH layers. Therefore, to prepare polymer/LDH nanocomposites, it is necessary to modify the pristine LDHs in order to alter the surface properties and to facilitate the intercalation of polymers [15]. Organic or polymeric anions, such as alkyl carboxylates, alkyl sulfates, polyacrylates, can be intercalated into the LDH interlayer by ion exchange or in situ polymerization much like as in layered silicates - or can be introduced during the LDH synthesis - when the co-precipitation method is used; these organic anions can render the hydrophilic LDHs surfaces hydrophobic and is accompanied by an expansion of the basal spacing [16].

In previous work from these laboratories, it was found that the variation of the divalent metal cations in a series of aluminumcontaining LDHs affects dispersion, thermal and fire properties of their PMMA composites as measured by the cone calorimetry [17]. The combustion behavior of PMMA/LDH composites showed better improvement in fire properties relative to what has usually been obtained for PMMA/layered silicate nanocomposites, and this behavior was found to correlate with the type of the charge balancing anion in the LDH precursor (e.g. carboxylate, phosphates, phosphonates) [18] and the anion chain lengths [19]. The trivalent metal has also been varied ( $\mathrm{Al}$ and $\mathrm{Fe}$ ) with $\mathrm{Ca}$ as the divalent metal. The aluminumcontaining system shows better dispersion than that containing iron [20]. Beyond PMMA, reports also exist where organically modified layered double hydroxides show efficacy in improving the fire properties of non-polar polymers. For example, Constantino et al. reported a $55 \%$ reduction in PHRR after melt blending zinc aluminum stearate LDH with low-density polyethylene, at just $5 \%$ inorganic loading [13].

Polymer, Vol. 50, No. 15 (July 2009): pg. 3564-3574. DOI. This article is (C Elsevier and permission has been granted for this version to appear in e-Publications@Marquette. Elsevier does not grant permission for this article to be further copied/distributed or hosted elsewhere without the express permission from Elsevier. 
In this work, it is shown that a zinc aluminum oleate LDH also enhances the fire properties of polyethylene, suggesting that zinc aluminum LDHs intercalated with long organophilic anions may be an effective additive for polyethylene. The goal of this work is to provide detailed evidence showing how to match a layered double hydroxide with a particular polymer. In order to compare an essentially non-polar polymer against a polar polymer, polyethyelene and poly(methyl methacrylate) are studied, and, for the thermal and flammability studies, poly(ethylene-co-butyl acrylate) is also studied, as a polymer with intermediate polar character. A correlation between the divalent metal in aluminum-containing LDHs on the morphology, thermal and fire properties of the resulting composites is then provided. Oleate anions were chosen as the charge balancing anions because these 18carbon long anions should compatibilize LDH with all three polymers [19]; also, the unusual packing [21] of these organic anions in LDH gallery may facilitate their easier incorporation into polymers, leading to better nanocomposite formation. Finally, zinc, magnesium and aluminum were chosen as the LDH metals, since they yield more environmentally friendly materials, a key factor in the design of new polymer additives.

\section{Experimental}

\subsection{Materials}

Zinc nitrate hexahydrate (98\%), magnesium nitrate hexahydrate $(99 \%)$, aluminum nitrate nonahydrate $(98 \%)$, and sodium hydroxide, extra pure pellets, were purchased from Aldrich Chemical Co. Sodium oleate $\left(\mathrm{CH}_{3}\left(\mathrm{CH}_{2}\right)_{7} \mathrm{CH}=\mathrm{CH}\left(\mathrm{CH}_{2}\right)_{7} \mathrm{COO}^{-} \mathrm{Na}^{+}\right)$, powder, purified, was obtained from J.T. Baker. Poly(methyl methacrylate) (PMMA), nominal $M_{\mathrm{w}} 120,000$ and poly(ethylene-cobutyl acrylate) (PEBuA), 7\% wt.\% butyl acrylate, were also obtained from Aldrich Chemical Co. Low-density polyethylene (PE) Petrothene NA960000, density $0.920 \mathrm{~g} / \mathrm{cm}^{3}$ and melt flow rate $1 \mathrm{~g} / 10 \mathrm{~min}$ $\left(190^{\circ} \mathrm{C} / 2.16 \mathrm{~kg}\right)$, was supplied by Equistar Chemicals Co.

\subsection{Synthesis of the oleate-containing LDHs}

The oleate-containing LDH was synthesized following the coprecipitation method [22]. This method requires the addition of an

Polymer, Vol. 50, No. 15 (July 2009): pg. 3564-3574. DOI. This article is (C Elsevier and permission has been granted for this version to appear in e-Publications@Marquette. Elsevier does not grant permission for this article to be further copied/distributed or hosted elsewhere without the express permission from Elsevier. 
$\mathrm{M}^{\mathrm{II}} / \mathrm{M}^{\mathrm{III}}$ metal salt solution to a basic solution of the desired anions [23]. In a typical experiment, in a $3000 \mathrm{ml}$ three neck flask under a flow of nitrogen to exclude $\mathrm{CO}_{2}, 1000 \mathrm{ml}$ of distilled water was boiled for 30 min while purging with nitrogen, then cooled to room temperature. To this, 0.12 mol of sodium oleate was added and the solution was stirred until homogenous. In a separate flask, a solution of magnesium nitrate $(0.2 \mathrm{~mol})$ and aluminum nitrate $(0.1 \mathrm{~mol})$ in $500 \mathrm{ml}$ of degassed water was prepared. The nitrate solution was slowly added dropwise to the stirred sodium oleate solution at room temperature, maintaining the $\mathrm{pH}$ at $10.0 \pm 0.1$, using a $1 \mathrm{M} \mathrm{NaOH}$ solution. After all the nitrate solution was added, the resulting slurry was aged for $24 \mathrm{~h}$ at $80^{\circ} \mathrm{C}$, filtered, washed (degassed water under nitrogen flow) and dried in a vacuum oven at $65^{\circ} \mathrm{C}$ for $12 \mathrm{~h}$ to yield magnesium aluminum oleate $\mathrm{LDH}$, denoted hereafter as MgAl. The synthesis of the zinc aluminum oleate LDH (denoted as ZnAl) was performed as described above except that magnesium nitrate was replaced by zinc nitrate.

\subsection{Nanocomposite preparation}

The nanocomposites were prepared in a Brabender Plasticorder at high speed (60 rpm) at $185^{\circ} \mathrm{C}$ for PMMA and at $140{ }^{\circ} \mathrm{C}$ for PE and PEBuA. The residence time in the Brabender mixer was $10 \mathrm{~min}$ for all composites. The composition of each nanocomposite is calculated from the amount of layered double hydroxide (wt.\%) and polymer charged to the Brabender.

\subsection{Analyses}

Fourier transform infrared (FTIR) spectra of the solid materials were obtained using the $\mathrm{KBr}$ method on a Nicolet Magna-IR 560 spectrometer operated at $1 \mathrm{~cm}^{-1}$ resolution in the $400-4000 \mathrm{~cm}^{-1}$ region. Elemental analysis was carried out by Huffman Labs, Colorado, using atomic emission spectroscopy interfaced with inductively coupled plasma (AES-ICP) for metal determination. Thermogravimetric analysis (TGA) was performed on a SDT 2960 machine (TA instrument) at the $15 \mathrm{mg}$ scale under a flowing nitrogen or air atmosphere at a scan rate of $20^{\circ} \mathrm{C} / \mathrm{min}$. Temperatures are reproducible to $\pm 3^{\circ} \mathrm{C}$, while the fraction of non-volatile materials has error bars of $\pm 2 \%$. TGA was done in duplicate and the averages are reported. X-ray diffraction

Polymer, Vol. 50, No. 15 (July 2009): pg. 3564-3574. DOI. This article is (C Elsevier and permission has been granted for this version to appear in e-Publications@Marquette. Elsevier does not grant permission for this article to be further copied/distributed or hosted elsewhere without the express permission from Elsevier. 
measurements (XRD) were performed on a Rigaku, Miniflex II desktop $X$-ray diffractometer; data acquisition was performed using a scan speed of $2 \% \mathrm{~min}$, at a sampling width of $0.020^{\circ}$, over a $2 \theta$ range from $2^{\circ}$ to $40^{\circ}$ for the LDHs, $2^{\circ}$ to $10^{\circ}$ for the composites and $2^{\circ}$ to $70^{\circ}$ for the cone residues. Bright field transmission electron microscopy (TEM) was performed in a JEOL 1200 EXII microscope, equipped with a Tietz F224 digital camera, and operated at an accelerating voltage of $80 \mathrm{kV}$. Sections of the nanocomposites were obtained with a Leica Ultracut UCT microtome, equipped with a diamond knife. The sections were transferred to carbon-coated copper grids (200-mesh), with or without a carbon lace, and imaged without any heavy metal staining. Cone calorimeter measurements were performed on an Atlas CONE-2 according to ASTM E 1354 at an incident flux of $50 \mathrm{~kW} / \mathrm{m}^{2}$, using a cone shaped heater; the exhaust flow was set at $24 \mathrm{~L} / \mathrm{s}$. The specimens for cone calorimetry were prepared by compression molding of the sample (about $30 \mathrm{~g}$ ) into $3 \mathrm{~mm}$ thick $100 \times 100 \mathrm{~mm}^{2}$ square plaques. Typical results from cone calorimetry are reproducible to within about $\pm 10 \%$ [24], 24a and 24b.

\section{Results and discussion}

\subsection{Characterization of the organically modified LDHs}

The presence and type of the organic ions in the gallery space of layered nanoparticles typically determines the formation of polymer/inorganic nanocomposites. Thus, the first step in this work was to synthesize LDHs with organophilic oleate anions which are long enough to promote miscibility [25] and, at the same time, expand the gallery space to facilitate fast incorporation of polymers in the interlayer spacings [26]. The composition of the LDHs was calculated from elemental analysis as: $\mathrm{Mg}_{2.10} \mathrm{Al}_{1.00}(\mathrm{OH})_{6.20}$ (oleate) $)_{1.00} \cdot 2.21 \mathrm{H}_{2} \mathrm{O}$ and $\mathrm{Zn}_{2.49} \mathrm{Al}_{1.00}(\mathrm{OH})_{6.98}$ (oleate) $)_{1.00} \cdot 2.02 \mathrm{H}_{2} \mathrm{O}$. The water content for both materials (7.1\% and $5.1 \%$ for $\mathrm{MgAl}$ and $\mathrm{ZnAl}$, respectively) was estimated by TGA experiments (air, $20^{\circ} \mathrm{C} / \mathrm{min}, 50-800^{\circ} \mathrm{C}$ ).

Both oleate modified LDHs, MgAl and ZnAl, were characterized by thermogravimetric analysis in an air environment at $20^{\circ} \mathrm{C} / \mathrm{min}$ (Fig. 1A). Both materials are thermally stable up to $270{ }^{\circ} \mathrm{C}$, the mass loss below this temperature is ascribed to the loss of intergallery water in accordance with the typical behavior of organically modified LDHs,

Polymer, Vol. 50, No. 15 (July 2009): pg. 3564-3574. DOI. This article is @ Elsevier and permission has been granted for this version to appear in e-Publications@Marquette. Elsevier does not grant permission for this article to be further copied/distributed or hosted elsewhere without the express permission from Elsevier. 
whereas the weight loss between $270^{\circ} \mathrm{C}$ and the high temperature plateau (above $450 \mathrm{C}$ ) is due to the thermal decomposition of intercalated organic anions. This thermal stability allows for meltprocessing of all composites in this study: PMMA/LDH composites were processed at $185^{\circ} \mathrm{C}$, whereas composites of LDH with both PE and PEBuA were processed at $140^{\circ} \mathrm{C}$. In addition, $\mathrm{ZnAl}$ had more residue at $800{ }^{\circ} \mathrm{C}$ compared to $\mathrm{MgAl}$, as expected based on compositions. The residue observed for $\mathrm{ZnAl}$ and $\mathrm{MgAl}, 36 \%$ and 26\%, respectively, compare well with the expected percentages based on the proposed formulae from elemental analysis, assuming mixed metal oxides are produced after heating these materials to $800{ }^{\circ} \mathrm{C}$.

In Fig. $1 \mathrm{~B}$, the thermal stability of $\mathrm{Zn}(\mathrm{OH})_{2}$ and commercial metal hydroxides of $\mathrm{Mg}(\mathrm{OH})_{2}$ [magnesium hydroxide, $\mathrm{MDH}$ ] and $\mathrm{Al}_{2} \mathrm{O}_{3} \cdot 3 \mathrm{H}_{2} \mathrm{O}$ [alumina trihydrate, $\mathrm{ATH}$ ] are compared. $\mathrm{MDH}$ is the most stable of the three materials and shows its maximum degradation step above $400{ }^{\circ} \mathrm{C}$, followed by $\mathrm{ATH}$ around $300^{\circ} \mathrm{C}$, while $\mathrm{Zn}(\mathrm{OH})_{2}$ shows its main degradation event at $154^{\circ} \mathrm{C}$. When considering these nanoparticles for use as polymer additives, this thermal stability indicates that it is advantageous to use $\mathrm{ZnAl}$, rather than combining $\mathrm{Zn}(\mathrm{OH})_{2}$ and $\mathrm{ATH}$, for polymers requiring processing temperatures above $150^{\circ} \mathrm{C}$; a rather moderate processing temperature which encompasses most of the thermoplastics, for example, PS, PP, or PMMA are processed in the Brabender mixer in the temperature range $180-190^{\circ} \mathrm{C}$.

The FTIR spectra of ZnAl and MgAl show the typical IR characteristics of long-chain carboxylate LDH compounds [21]: a broad band at $\sim 3500 \mathrm{~cm}^{-1} V_{\mathrm{OH}}$ of layer hydroxide), the asymmetric and symmetric $V_{\mathrm{CH}}$ at $3000-2800 \mathrm{~cm}^{-1}$ and two strong bands at $1600-$ $1400 \mathrm{~cm}^{-1}$ (asymmetric and symmetric carboxylate bands). There is also a distinctive oleate feature: the weak peak at $3012 \mathrm{~cm}^{-1}$ associated with $v_{\mathrm{CH}}$ attached to a double bond [27]. All the above peaks confirm the presence of the oleate carboxylate chains in ZnAl and $\mathrm{MgAl}$.

Fig. 2 shows the XRD traces of the two oleate-containing LDHs. Both materials show well stacked interlayer structures with higher order reflections visible in each case, indicating long range ordering in the $c$-direction. The $\mathrm{d}_{003}$-spacings are found to be $3.8 \mathrm{~nm}$ for $\mathrm{ZnAl}$ and $3.4 \mathrm{~nm}$ for $\mathrm{MgAl}$, with at least three higher order Bragg reflections

Polymer, Vol. 50, No. 15 (July 2009): pg. 3564-3574. DOI. This article is @ Elsevier and permission has been granted for this version to appear in e-Publications@Marquette. Elsevier does not grant permission for this article to be further copied/distributed or hosted elsewhere without the express permission from Elsevier. 
visible for ZnAl and one for MgAl, in good agreement with previous work [21]. The slightly larger d-spacing of ZnAl relative to MgAl reflects the different amount of oleate anions and water in the galleries of these two LDHs, and possibly differences in packing of the interlayer oleates [21] or presence of excess organic (if any) in the gallery.

Compared to organically modified cationic clays - i.e., layered 2:1 alumino silicates - the basal d-spacing observed for LDHs organically modified with similar size organic ions is considerably larger [28], 28a, 28b, 28c, 28d and 28e. This behavior reflects the higher ion exchange capacity of the LDHs, and their respective even higher surface charge density; the typical value for an LDH is 4.12 charge/nm compared to 1.43 charge/nm for an MMT. In the present study, where the organic modification is a long monounsaturated alkene, the interlayer $\mathrm{d}$-spacing is increased even more, due to the more extended conformations imposed by the double bond [21], $28 \mathrm{e}$ and [28]. Regarding the comparative applicability of these two classes of layered nanoparticulates in forming polymer nanocomposites, this difference is expected to result in less favorable thermodynamics of mixing, e.g. compared to similarly modified montmorillonite [25], but faster kinetics of intercalation [26]. For the specific case of oleate modified $\mathrm{ZnAl}$ and $\mathrm{MgAl}$, this situation is improved since these particles show smaller lateral dimensions than typical for LDHs, in agreement with previous literature [21], and consequently should be easier to disperse and exfoliate.

\subsection{Morphology of the nanocomposites}

After melt blending the LDH with polymers, the morphology of the (nano)composites was assessed via XRD and TEM. Fig. 3 provides the XRD traces of 3\% MgAl melt-blended with PE and PMMA. For both oleate LDHs, the 003 diffraction peaks disappear when blended with PMMA, an indication of either the formation of exfoliated nanocomposites or a disordered system. In contrast, for PE the 003 diffraction peaks either do not shift to lower $2 \theta$ values (MgAl) or show a moderate $(0.3 \mathrm{~nm})$ increment in d-spacing $(\mathrm{ZnAl})$ but in both cases they are substantially less intense. This suggests either the existence of immiscible LDHs (i.e., no PE intercalation, and the intensity decrease is simply due to the low ( $3 \mathrm{wt} . \%$ ) loading of LDH in the composite), or the possibility of limited only PE intercalation in the LDH gallery (for example, PE replacing the interlayer water and

Polymer, Vol. 50, No. 15 (July 2009): pg. 3564-3574. DOI. This article is (C Elsevier and permission has been granted for this version to appear in e-Publications@Marquette. Elsevier does not grant permission for this article to be further copied/distributed or hosted elsewhere without the express permission from Elsevier. 
restructuring the oleate conformations, both of which can be achieved without marked change of the interlayer spacing). In all cases, the higher order 0012 reflections of the oleate LDH disappear, which strongly indicates increased disordering of the tactoid stacking.

The composite morphology can be directly observed via bright field transmission electron microscopy (TEM). The TEM images at low magnification are used to determine the overall dispersion of the layered material in the polymer, while the higher magnification image provide more detail on the nanometer scale dispersion (e.g. intercalated or exfoliated morphologies). In all cases, we could not obtain ultra-thin microtomed specimens that could survive a prolonged exposure to the TEM electron beam, and therefore our ability to image at very high magnifications was limited. Fig. 4 shows representative TEM images of PE/3\% MgAl (Fig. 4A) and PE/3\% ZnAl (Fig. 4B). (All of the images that have been obtained confirm the interpretation expressed herein.) The lower magnification images for both LDHs in PE shows relatively poor dispersion, with sub-micrometer tactoids (agglomeration of LDHs) observed for both systems, ZnAl seems better dispersed in PE than is MgAl, with larger tactoids present in $\mathrm{PE} / 3 \% \mathrm{MgAl}$ compared to PE/3\% ZnAl. This observation is in concert with the XRD data, which also indicated a small increase in d-spacing for ZnAl and none for MgAl. Combining the XRD and TEM observations, the composite morphology can probably be described as intercalated with disordering for $\mathrm{PE} / 3 \% \mathrm{ZnAl}$, while a microcomposite (no nanoscale filler dispersion) is probably formed in the case of $\mathrm{PE} / 3 \%$ MgAl.

The composite morphology is qualitatively different for the PMMA-based composites. Fig. 5 shows the TEM images of PMMA containing 3 wt.\% MgAl (Fig. 5A) and 3 wt.\% ZnAl (Fig. 5B). The lower magnification images of both systems show relatively good dispersion, with only a few tactoids observed for the ZnAl-containing PMMA/LDH system, and these are much smaller in size than those in the PE composites. Comparison of the two PMMA composites indicates better dispersion of $\mathrm{MgAl}$ oleate than of the $\mathrm{ZnAl}$ oleate. This trend in dispersion is opposite to what is seen for the PE systems, where ZnAl shows better dispersion than MgAl.

All TEM images indicate that these LDHs have smaller particle sizes than typically seen in LDHs. This is in agreement with previous

Polymer, Vol. 50, No. 15 (July 2009): pg. 3564-3574. DOI. This article is (C Elsevier and permission has been granted for this version to appear in e-Publications@Marquette. Elsevier does not grant permission for this article to be further copied/distributed or hosted elsewhere without the express permission from Elsevier. 
work [21], where it was reported that co-precipitated zinc aluminum oleate showed structures quite different from the regular hexagonal platy sheets of an inorganic LDH, [29], 29a and 29b exhibiting homogenous submicron platy sheets (tactoids) containing small irregular particles [21]. In order to confirm that this is also the case here for MgAl, and also to confirm that the thickness of the microtomed specimens is not a factor, we extracted the particles from the PMMA composite and observed them with TEM. Namely, PMMA/3\% MgAl was dissolved in acetone, and the solution was left to stand for 3 days before collecting the precipitant from the bottom of the vial, and cast on a lace-coated TEM grid. Fig. 6 shows images of these extracted particles. The LDH particle size is small, about $10-20 \mathrm{~nm}$ long. Individual layers are observed, and also stacks of 2-5 layers are seen. It is significant to note that small stacks and individual platelets all had relatively low aspect ratios LDHs layers (typical length of about $20 \mathrm{~nm}$ ).

\subsection{Thermogravimetric analysis}

The thermal properties of the different LDH/polymer systems were examined in both air and nitrogen environments. As summarized in Table 1 , in air, the nanocomposites are more thermally stable than the virgin polymers when the $10 \%\left(T_{0.1}\right)$ or $50 \%\left(T_{0.5}\right)$ mass loss temperatures are used as the points of comparison. The destabilization effect of oxygen is noted comparing TGA curves of the virgin polymers in air and nitrogen, due to reactions of the degrading polymer radicals with oxygen in air [13]. The initial results were obtained using the $\mathrm{ZnAl} \mathrm{LDH}$ and, since the greatest effect in all techniques was found at $10 \%$, only $10 \% \mathrm{MgAl}$ composites were studied. The MgAl LDH contains $26 \%$ inorganic while the $\mathrm{ZnAl}$ LDH contains 36\% inorganic; thus $10 \%$ $\mathrm{LDH}$ corresponds to $2.6 \%$ inorganic for MgAl and 3.6\% for $\mathrm{ZnAl}$.

Fig. 7 shows that the presence of the LDH pushes the TGA curves of the composites in air towards the corresponding virgin polymers run in a nitrogen environment. The TGA curves for PE/ZnAl and PE/MgAl are quite similar to those of the PEBuA system and consequently the PE curves are not shown here. This behavior points out that the presence of the hydrotalcite-like lamellae produces a barrier effect to oxygen diffusion into the heated polymer due to the accumulation of the oxides produced by thermal degradation of the hydrotalcite on the surface of the volatizing polymer [12a].

Polymer, Vol. 50, No. 15 (July 2009): pg. 3564-3574. DOI. This article is @ Elsevier and permission has been granted for this version to appear in e-Publications@Marquette. Elsevier does not grant permission for this article to be further copied/distributed or hosted elsewhere without the express permission from Elsevier. 
NOT THE PUBLISHED VERSION; this is the author's final, peer-reviewed manuscript. The published version may be accessed by following the link in the citation at the bottom of the page.

Overall, increasing the LDH loading from 1 to $10 \%$ enhances the thermal stability of the composites. It is noted that, at $10 \%$ mass loss, 10 wt. $\%$ ZnAl gives an improvement of $45^{\circ} \mathrm{C}, 28{ }^{\circ} \mathrm{C}$ and $16{ }^{\circ} \mathrm{C}$, and 10 wt. $\%$ MgAl gives $36{ }^{\circ} \mathrm{C}, 39{ }^{\circ} \mathrm{C}$ and $33^{\circ} \mathrm{C}$ improvements in PE, PEBuA and PMMA, respectively. These data suggest greater interaction of MgAl with the polar polymers (PMMA and PEBuA), while $\mathrm{ZnAl}$ is more effective in enhancing the thermal stability of the non-polar PE. This is also shown in Fig. 8 where PMMA/10\% MgAl system is the best system for PMMA; relative to the PMMA control sample, the onset temperature of this system shows a $33^{\circ} \mathrm{C}$ improvement in an air environment, and is more thermally stable than even the control PMMA run in a nitrogen environment $\left(16^{\circ} \mathrm{C}\right.$ increase in $T_{0.5}$, as can also be observed in Fig. 8).

\subsection{Flammability properties}

The fire properties of these new composites were evaluated using the cone calorimeter at $50 \mathrm{~kW} / \mathrm{m}^{2}$ and the summary of the results is given in Table 2 . The data reported are the peak heat release rate (PHRR) and its relative reduction from the virgin polymer, the time to PHRR, $t_{P H R R}$, the average mass loss rate, AMLR, and the timeto-ignition, $t_{\text {ign. }}$ With $\mathrm{ZnAl}$, it is noted that a loading of $10 \mathrm{wt} . \%$ is required to achieve a large reduction in PHRR (58\%). As can be seen in the summary table and graphically in Fig. 9, ZnAl performs well with PE, while only modest reductions in PHRR are obtained with PEBuA and PMMA. Considering the $\pm 10 \%$ error bars on the cone calorimeter parameters, the presence of the $\mathrm{ZnAl} \mathrm{LDH}$ at any concentration has no effect on the fire properties of PeBuA. The large reduction in PHRR for $\mathrm{PE} / 10 \% \mathrm{ZnAl}$ is accompanied by a substantial decrease in average mass loss rate. This suggests that the lower HRR of nanocomposites is caused by the reduction of MLR and that the enhanced flame retardancy of $\mathrm{PE} / \mathrm{ZnAl}$ nanocomposites is due to modifications taking place in the condensed phase during polymer combustion, as also observed by Costantino et al. [13].

The cone results of MgAl with different polymers are summarized in Table 3 and the HRR curves are provided in Fig. 10. With the more polar polymer, PMMA, a larger reduction in PHRR (48\%) is noted for $10 \% \mathrm{MgAl}$, while $\mathrm{ZnAl}$ gives $29 \%$ reduction at a similar loading. A magnesium aluminum undecenoate LDH has also been melt-blended with PMMA and TEM images of that system reveals good

Polymer, Vol. 50, No. 15 (July 2009): pg. 3564-3574. DOI. This article is (C Elsevier and permission has been granted for this version to appear in e-Publications@Marquette. Elsevier does not grant permission for this article to be further copied/distributed or hosted elsewhere without the express permission from Elsevier. 
dispersion, perhaps at the nanolevel; $10 \%$ of that LDH gives $52 \%$ reduction in PHRR [19]. These results for $\mathrm{MgAl}$ are better than that from previous work on PMMA/LDH in this laboratory, where an LDH of magnesium aluminum modified with 4-styrene sulfonate gave a reduction of $33 \%$ in the PHRR [30]. The above results suggest that combination of the appropriate anion, probably long organophilic chains, with the proper selection of metals, magnesium and aluminum, in $\mathrm{LDH}$ is an important factor towards enhancing the fire properties of PMMA.

To simplify the interpretation of cone calorimetric data, as these relate to the assessment of the hazard of developing fires, indices have been introduced, such as FIGRA [31] (fire growth rate, defined as the PHRR divided by the time to PHRR) and FPI [32] (fire performance index, $\mathrm{s} / \mathrm{kW}^{-1} / \mathrm{m}^{2}$, defined as the time-to-ignition divided by the PHRR). As can be seen in Table 4, these indices also show consistently a decrease of fire risk for the PMMA/10\% MgAl and PE/10\% ZnAl relative to the virgin polymers.

Fig. $11 \mathrm{~A}$ gives a comparison of the fire properties of $\mathrm{PE}$ composites with ZnAl and MgAl while Fig. 11B compares the effect of both LDHs on the flammability of PMMA. It is clearly observed that ZnAl performs well with $P E$, but not PMMA, while MgAl was the best system for PMMA but performs worse with $P E$. The reduction in the PHRR using 10 wt.\% ZnAl in PE is slightly larger than the reduction obtained using 3 wt. \% organically modified MMT [33]. The results from PE with 10\% ZnAI LDH compare favorably with those from PE with $3 \%$ MMT nanocomposites. When $10 \% \mathrm{MgAl} \mathrm{LDH}$ is used with PE, only a modest reduction is observed.

\subsection{Analysis of the cone residue}

Fig. 12 shows the char remaining after cone calorimetry for each of the polymer/LDH systems at $10 \%$ additive loading. ZnAl has a more dense char when combined with $\mathrm{PE}$, while MgAl produces more char with PMMA. In both cases, the char is compact and covers a large amount of the aluminum foil. In the PEBuA systems, neither of the 2 LDHs leaves a compact inorganic residue after cone test (tiny inorganic particulates are spread out on the aluminum foil with this polymer). Char formation results in enhancement of the fire properties, as the oxide formed produces a protective layer around the polymer matrix

Polymer, Vol. 50, No. 15 (July 2009): pg. 3564-3574. DOI. This article is (C Elsevier and permission has been granted for this version to appear in e-Publications@Marquette. Elsevier does not grant permission for this article to be further copied/distributed or hosted elsewhere without the express permission from Elsevier. 
as it burns. Weil and Patel [34] also reported that the mode of action of flame retardants appears to be connected to improved char morphology rather than quantity. This agrees well with the reductions in PHRR noted for PE/10\% ZnAl and PMMA/10\% MgAl as discussed earlier.

The XRD traces of the residue from PE/10\% ZnAl after cone calorimetry was collected after the cone calorimetry study, and after the same char was calcined at $1000{ }^{\circ} \mathrm{C}$ overnight. These XRD studies identified only $\mathrm{ZnO}$ as the crystalline phase after the cone experiment, whereas after heating the char to $1000{ }^{\circ} \mathrm{C}$, both the spinel, $\mathrm{ZnAl}_{2} \mathrm{O}_{4}$, and $\mathrm{ZnO}$ are identified [35]. This clearly shows that aluminum is present in the cone residue before calcination, but it is in an amorphous form, not detectable by XRD. Introducing ZnAl in different polymers (PMMA and PEBuA) did not change the identity of the crystalline phases in the residue, identified with XRD either after cone calorimetry, or after further calcinations at $1000^{\circ} \mathrm{C}$ for $12 \mathrm{~h}$. The same materials can be identified in the chars from PMMA/ZnAl and PEBuA/ZnAl; these have also been observed in previous work after burning PMMA containing a zinc aluminum undecenoate LDH [17].

Similarly, XRD traces of the cone residues of MgAl in PE, PEBuA and PMMA have been obtained. After the cone experiment, the diffraction peaks of these residues are broad and make the identification using XRD very difficult. However, the positions and relative intensities of the two main diffraction peaks support the formation of a poorly crystallized $\mathrm{MgO}$. This phase is broader for $\mathrm{PMMA} / 10 \% \mathrm{MgAl}$ relative to the other two systems, PEBuA/10\% MgAl and PE/10\% MgAl. The more amorphous-like char (broader XRD peaks) was obtained for the system that gives the best reduction in PHRR. This poorly crystalline char also corresponds to the more compact char relative to the other two chars. When the chars were calcined by heating to $1000^{\circ} \mathrm{C}$, another crystalline phase, the spinel $\mathrm{MgAl}_{2} \mathrm{O}_{4}$ can be indexed along with $\mathrm{MgO}$.

\subsection{Mechanical properties}

The tensile strength and elongation at break of the polymer/LDH systems were measured using an Instron and the data are summarized in Table 5. It is well known that the mechanical properties of nanocomposites based on layered silicates are typically enhanced relative to those of the virgin polymer. Little work on mechanical

Polymer, Vol. 50, No. 15 (July 2009): pg. 3564-3574. DOI. This article is @ Elsevier and permission has been granted for this version to appear in e-Publications@Marquette. Elsevier does not grant permission for this article to be further copied/distributed or hosted elsewhere without the express permission from Elsevier. 
properties of LDH based polymer composites has been reported. As noted in the summary table, replacing the polymer with the LDH additive lowers the tensile strength of the composite. For PEBuA, neither additive reduces markedly the ductility of the polymer, i.e., the elongation at break changes from $810 \%$ to $760 \%$ for either $\mathrm{ZnAl}$ or $\mathrm{MgAl}$. For PE, ZnAl enhances the elongation at break compared to the unfilled polymer, while MgAl greatly decreases it. For PMMA, the LDHs give much smaller changes in the mechanical properties, but as the elongation at break of PMMA is usually small, this behavior is as expected. It is reasonable to expect that preparing LDH with a larger aspect ratios would improve more the mechanical properties of the resulting nanocomposites. With PE and PMMA, the elongation at break results are in concert with what is expected when considering the differences in dispersion; ZnAl giving better results in PE relative to $\mathrm{MgAl}$, and the opposite being true with PMMA, where MgAl performs better than $\mathrm{ZnAl}$. This trend also parallels the cone results (reduction in PHRR). With PEBuA, however, no strong correlation between cone data and mechanical testing is seen.

\subsection{Control experiments}

To test the efficacy of the $\mathrm{ZnAl}$ and $\mathrm{MgAl}$ LDHs relative to commercial metal hydroxides, PE was melt-blended with combinations of $\mathrm{Zn}(\mathrm{OH})_{2}$ or $\mathrm{Mg}(\mathrm{OH})_{2}$ and $\mathrm{Al}(\mathrm{OH})_{3}$, which simulated the metal contents in both $5 \%$ and $10 \% \mathrm{ZnAl}$ or MgAl LDHs. In addition, the combination of the two metal hydroxides resembling $\mathrm{ZnAl}$ or $\mathrm{MgAl}$ were added to PE at a $10 \%$ combined loading (wt.\%). The fire and mechanical properties of these new composites are compared to the $\mathrm{PE} / \mathrm{ZnAl}$ systems.

In either combination, introduction of the mixtures of commercial metal hydroxides in PE greatly deteriorated the mechanical properties (Table 6). Also, neither combination leads to any improvement in fire properties, despite using ratios of these metal hydroxides that mimic the present LDHs metal content, as summarized in Table 7. These results highlight the advantage of using a layered double hydroxide instead of the corresponding metal hydroxides. The poorer performance of the zinc-containing metal hydroxide systems, relative to these of magnesium, may arise from the earlier decomposition of zinc hydroxide to $\mathrm{ZnO}$, which occurs before any

Polymer, Vol. 50, No. 15 (July 2009): pg. 3564-3574. DOI. This article is (C Elsevier and permission has been granted for this version to appear in e-Publications@Marquette. Elsevier does not grant permission for this article to be further copied/distributed or hosted elsewhere without the express permission from Elsevier. 
significant degradation of the polymer and therefore cannot influence polymer degradation.

It is known that the LDH properties (exchange, reconstruction, exfoliation, crystallinity) are not easily transferable from one to another [8]. However, the two LDHs studied here were prepared under similar conditions, and both contain the same oleate anions. The main difference between the two LDHs was the replacement of magnesium by zinc, and $\mathrm{Mg}^{2+}$ is a little smaller than $\mathrm{Zn}^{2+}(0.66 \AA$ vs. $0.74 \AA)$ [36], and lighter (atomic weights: $\mathrm{Mg}, 24.304 ; \mathrm{Zn}, 65.38$ ). Both LDH anion exchange capacities were calculated to be about 200 mequiv/100 g. If one only considers the AEC, the compatibility and the fire performance of each LDH should be similar with either polymer. But it is found that ZnAl performs selectively well with PE but not with PMMA, while MgAl does the opposite. Also, neither of the two LDHs gave any improvement with PEBuA. This finding clearly shows that there are other factors that play important roles in the fire behavior of the $\mathrm{LDH} /$ polymer systems. Comparing the results of the various composites, it seems that the necessary condition for good performance is a good dispersion, which depends not only on AEC and anion type, but also on the lateral size of the LDH. MgAl shows better dispersion in PMMA relative to the $\mathrm{ZnAl}$, while the opposite is observed in PE. One can then postulate that better improvement in fire, thermal and mechanical properties may be obtained if one can match the appropriate LDH with a given polymer, but also, produce LDH materials with larger aspect ratio layers.

\section{Conclusions}

Polymer nanocomposites of polyethylene, poly(ethylene-cobutyl acrylate) and poly(methyl methacrylate) were prepared using two oleate-containing LDHs as the nanomaterials. The unusual packing of oleate anions in the gallery of the LDH leads to larger basal spacings for both $\mathrm{ZnAl}$ and $\mathrm{MgAl}$, which facilitate incorporation of polymer between the gallery of the LDHs. It is found that matching an LDH with a given polymer is a key in using these layered nanomaterials as additives for polymers. TEM images reveal that the MgAl disperses better in PMMA than does ZnAl and that the opposite is true for PE where $\mathrm{PE} / 3 \% \mathrm{ZnAl}$ shows less $\mathrm{LDH}$ aggromelates relative to $\mathrm{PE} / 3 \%$ MgAl. The nanocomposites are more thermally stable than the pure polymers, with larger improvement for PE obtained with ZnAl, while

Polymer, Vol. 50, No. 15 (July 2009): pg. 3564-3574. DOI. This article is (C Elsevier and permission has been granted for this version to appear in e-Publications@Marquette. Elsevier does not grant permission for this article to be further copied/distributed or hosted elsewhere without the express permission from Elsevier. 
MgAl enhances the thermal stability of the more polar polymers. No marked deterioration in mechanical properties is noted upon introductions of these LDHs. However, when metal hydroxides were melt-blended with the same polymer, poorer mechanical properties are observed.

A reduction in PHRR of $58 \%$ is recorded for $\mathrm{PE} / 10 \% \mathrm{ZnAl}$ while a modest reduction is recorded for $\mathrm{PE} / 10 \% \mathrm{MgAl}$. It is noted that $\mathrm{MgAl}$ improves the fire properties of PMMA systems; neither of these systems offer any improvement in PEBuA. It was concluded that with oleate as the charge balancing anions of the layered double hydroxide, magnesium-containing LDHs are the best choice as additives for PMMA systems while zinc-containing LDHs are best for PE systems. Comparing these results with the literature, it can be postulated that zinc aluminum LDH intercalated with long organophilic carboxylate anions may perform well with non-polar polymeric systems. More work is underway to understand all of the factors that are important.

\section{Acknowledgements}

This work was performed under the sponsorship of the US Department of Commerce, National Institute of Standards and Technology, Grant 60NANB6D6018.

\section{References}

1. (a) Theng BKG. Formation and properties of clay-polymer complexes. Amsterdam: Elsevier; 1979;

(b) Theng BKG. Chemistry of clay-organic reactions. NewYork: Wiley; 1974.

2. Kojima Y, Usuki A, Kawasumi M, Okada A, Fukushima $Y$, Kurauchi TT, et al. Mater Res 1993;8:1179; Kojima Y, Usuki A, Kawasumi M, Okada A, Fukushima Y, Kurauchi TT, et al. J Polym Sci A Polym Chem 1993;31:983.

3. Vaia RA, Ishii H, Giannelis EP. Chem Mater 1993;5:1694.

4. Vaia RA, Jandt KD, Kramer EJ, Giannelis EP. Macromolecules $1995 ; 28: 8080$.

5. (a) Okada A, Usuki A. Macromol Mater Eng 2006;291:1449;

(b) Sinha Ray S, Okamoto M. Prog Polym Sci 2003;28:1539;

Polymer, Vol. 50, No. 15 (July 2009): pg. 3564-3574. DOI. This article is @ Elsevier and permission has been granted for this version to appear in e-Publications@Marquette. Elsevier does not grant permission for this article to be further copied/distributed or hosted elsewhere without the express permission from Elsevier. 
NOT THE PUBLISHED VERSION; this is the author's final, peer-reviewed manuscript. The published version may be accessed by following the link in the citation at the bottom of the page.

(c) Zhang J, Manias E, Wilkie CAJ. Nanosci Nanotechnol 2008;8:1597.

6. (a) Lincoln DM, Vaia RA, Wang ZG, Hsiao BS, Krishnamoorti R. Polymer 2001;42:9975; Lincoln DM, Vaia RA, Wang ZG, Hsiao BS, Krishnamoorti R. Polymer 2001;42:1621;

(b) Strawhecker KE, Manias E. Chem Mater 2000;12:2943;

(c) Strawhecker KE, Manias E. Macromolecules 2001;34:8475;

(d) Lincoln DM, Vaia RA, Krishnamoorti R. Macromolecules $2004 ; 37: 4554$.

7. (a) Zhang J, Jiang DD, Wilkie CA. Thermochim Acta 2005;430:107;

(b) Su S, Jiang DD, Wilkie CA. Polym Degrad Stab 2004;84:269.

8. (a) Leroux F, Besse JP. Chem Mater 2001;13:3507;

(b) O'Leary S, O’Hare D, Seeley G. Chem Commun 2002:1506.

9. (a) Williams GR, O'Hare DJ. Mater Chem 2006;16:3065;

(b) Duan X, Evans DG. Chem Commun 2006:485;

(c) Costa FR, Saphiannikova M, Wagenknecht U, Heinrich G. Adv Polym Sci 2008;210:101.

10. Vaccari A. Appl Clay Sci 1999;14:161.

11. Guo S, Li D, Zhang W, Pu M, Evans DG, Duan XJ. Solid State Chem $2004 ; 177: 4597$.

12. (a) Camino G, Maffezzoli M, Braglia M, De Lazzaro M, Zammarano M. Polym Degrad Stab 2001;74:457;

(b) Ling S, Li D, Li SLi, Wang J, Evans DG, Duan X. Chin Sci Bull 2005;50:1101.

13. Costantino U, Gallipoli A, Nocchetti M, Camino G, Bellucci F, Frache A. Polym Degrad Stab 2005;90:586.

14. (a) Hibino T, Jones WJ. Mater Chem 2001;11:1321; Adachi-Pagano M, Forano C, Besse J. Chem Commun 2000:91.

15. Chen W, Qu B. Chem Mater 2003;15:3208.

16. Hussein MZB, Zainal Z, Ming CYJ. Mater Sci Lett 2000;19:879.

17. Manzi-Nshuti C, Wang D, Hossenlopp JM, Wilkie CAJ. Mater Chem 2008;18:3091.

Polymer, Vol. 50, No. 15 (July 2009): pg. 3564-3574. DOI. This article is @ Elsevier and permission has been granted for this version to appear in e-Publications@Marquette. Elsevier does not grant permission for this article to be further copied/distributed or hosted elsewhere without the express permission from Elsevier. 
NOT THE PUBLISHED VERSION; this is the author's final, peer-reviewed manuscript. The published version may be accessed by following the link in the citation at the bottom of the page.

18. Wang L, Su S, Chen D, Wilkie CA. Polym Degrad Stab 2009;94:770-81.

19. Nyambo C, Songtipya P, Manias E, Jimenez-Gasco MM, Wilkie CAJ. Mater Chem 2008; 18:4827-38.

20. Manzi-Nshuti C, Wang D, Hossenlopp JM, Wilkie CA. Polym Degrad Stab 2009;94:705-11.

21. Xu ZP, Braterman PS, Yu K, Xu H, Wang Y, Brinker CJ. Chem Mater 2004; $16: 2750$.

22. Wang GA, Wang CC, Chen CY. Polymer 2005;46:5065.

23. Hibino T. Chem Mater 2004;16:5482.

24. (a) Gilman JW, Jackson CL, Morgan AB, Manias E, Giannelis EP, Wuthenow M, et al. Chem Mater 2000;12:1866;

(b) Gilman JW, Kashiwagi T, Nyden M, Brown JET, Jackson CL, Lomakin S, et al. In: Al-Malaika S, Golovoy A, Wilkie CA, editors. Chemistry and technology of polymer additives. Oxford: Blackwell Scientific; 1999. p. 249.

25. Vaia RA, Giannelis EP. Macromolecules 1997;30. 7990 and 8000; Balazs AC, Singh C, Zhulina E. Macromolecules 1998;31:8370; Ginzburg VV, Singh C, Balazs AC. Macromolecules 2000;33:1089.

26. Manias E, Chen H, Krishnamoorti R, Genzer J, Kramer EJ, Giannelis EP. Macromolecules 2000;33:7955.

27. Simons WW, editor. The Sadtler handbook of infrared spectra. Philadelphia, PA: Sadtler Research Laboratories, Inc.; 1978. p. 26, 710 , and 741.

28. (a) Carlino S. Solid State Ionics 1997;98:73;

(b) Meyn M, Beneke K, Lagaly G. Inorg Chem 1990;29:5201;

(c) Kanoh T, Shichi T, Tagaki K. Chem Lett 1999:117;

(d) Takagi K, Shichi T, Usami H, Sawaki Y. J Am Chem Soc 1993;115:4339;

(e) Xu ZP, Braterman PS. Layered double hydroxides: multiple phases and self-assembly, Encyclopedia of nanoscience and nanotechnology. New York: Marcel Dekker; 2003.

29. (a) Ogawa M, Asai S. Chem Mater 2000;12:3253;

(b) Labajos FM, Rives V, Ulibarri MA. J Mater Sci 1992;27:1546.

Polymer, Vol. 50, No. 15 (July 2009): pg. 3564-3574. DOI. This article is (C Elsevier and permission has been granted for this version to appear in e-Publications@Marquette. Elsevier does not grant permission for this article to be further copied/distributed or hosted elsewhere without the express permission from Elsevier. 
NOT THE PUBLISHED VERSION; this is the author's final, peer-reviewed manuscript. The published version may be accessed by following the link in the citation at the bottom of the page.

30. Costache MC, Wang D, Heidecker MH, Mania E, Wilkie CA. Polym Adv Technol 2006;17:272.

31. Schartel B, Hull TR. Fire Mater 2007;31:327.

32. Zanetti M, Camino G, Cavanese D, Morgan AB, Lamelas FJ, Wilkie CA. Chem Mater 2002;14:189.

33. Zhao C, Qin H, Gong F, Feng M, Zhang S, Yang M. Polym Degrad Stab $2005 ; 87: 183$.

34. Weil ED, Patel NG. Polym Degrad Stab 2003;82:291.

35. Powder diffraction file, Alphabetical indexes, Inorganic phases, JCPDS. Swartmore, PA: International Centre for Diffraction Data; 1999.

36. Meyn M, Beneke K, Lagaly G. Inorg Chem 1993;32:1209.

\section{About the Authors}

Charles A. Wilkie : Department of Chemistry and Fire Retardant Research Facility, Marquette University, Milwaukee, WI 53201-1881, USA

Email: charles.wilkie@marquette.edu

Polymer, Vol. 50, No. 15 (July 2009): pg. 3564-3574. DOI. This article is @ Elsevier and permission has been granted for this version to appear in e-Publications@Marquette. Elsevier does not grant permission for this article to be further copied/distributed or hosted elsewhere without the express permission from Elsevier. 
NOT THE PUBLISHED VERSION; this is the author's final, peer-reviewed manuscript. The published version may be accessed by following the link in the citation at the bottom of the page.

\section{Appendix}

Table 1: TGA summary results of $\mathrm{ZnAl}$ and $\mathrm{MgAl}$ with different polymers

\begin{tabular}{|c|c|c|c|c|c|}
\hline Material & $T_{0.1}$ & $\Delta T_{0.1}$ & $T_{0.5}$ & $\Delta T_{0.5}$ & Char \\
\hline \multicolumn{6}{|l|}{ AIR flow, $20^{\circ} \mathrm{C} / \mathrm{min}$} \\
\hline PE & 369 & NA & 424 & NA & 0 \\
\hline $\mathrm{PE} / 1 \% \mathrm{ZnAl}$ & 396 & 27 & 443 & 19 & 1 \\
\hline $\mathrm{PE} / 3 \%$ ZnAl & 412 & 43 & 446 & 22 & 1 \\
\hline $\mathrm{PE} / 5 \%$ ZnAl & 419 & 50 & 451 & 27 & 2 \\
\hline $\mathrm{PE} / 10 \%$ ZnAl & 414 & 45 & 450 & 26 & 4 \\
\hline $\mathrm{PE} / 10 \% \mathrm{MgAl}$ & 405 & 36 & 452 & 28 & 3 \\
\hline PEBuA & 374 & NA & 426 & NA & 0 \\
\hline PEBuA $1 \%$ ZnAl & 371 & -3 & 437 & 11 & 0 \\
\hline PEBuA/3\% ZnAl & 409 & 35 & 452 & 26 & 1 \\
\hline PEBuA15\% ZnAl & 400 & 26 & 469 & 43 & 2 \\
\hline PEBUA $10 \%$ ZnAl & 402 & 28 & 476 & 50 & 4 \\
\hline PEBuA $10 \% \mathrm{MgAl}$ & 413 & 39 & 479 & 53 & 2 \\
\hline PMMA & 265 & NA & 347 & NA & 0 \\
\hline PMMA $1 \%$ ZnAl & 276 & 11 & 364 & 17 & 1 \\
\hline PMMA/3\% ZnAl & 279 & 14 & 375 & 28 & 1 \\
\hline PMMA $5 \%$ ZnAl & 285 & 20 & 377 & 30 & 2 \\
\hline PMMA $10 \%$ ZnAl & 281 & 16 & 382 & 35 & 4 \\
\hline PMMA $10 \%$ MgAl & 298 & 33 & 373 & 26 & 3 \\
\hline \multicolumn{6}{|l|}{$\mathrm{N}_{2}$ flow, $20^{\circ} \mathrm{C} / \mathrm{min}$} \\
\hline $\mathrm{PE}$ & 444 & NA & 476 & NA & 0 \\
\hline PEBUA & 443 & NA & 472 & NA & 0 \\
\hline PMMA & 282 & NA & 374 & NA & 0 \\
\hline
\end{tabular}

Note: $T 0.1$ - temperature of $10 \%$ mass loss; T0.5 - temperature of $50 \%$ mass loss; $\Delta T$ - difference between virgin polymer and its composite.

Table 2: Cone summary data of ZnAl with PMMA, PEBuA and PE at $50 \mathrm{~kW} / \mathrm{m}^{2}$

\begin{tabular}{lllll}
\hline Formulation & $\begin{array}{l}\text { PHRR }\left(\mathrm{kW} / \mathrm{m}^{2}\right)(\% \\
\text { reduction })\end{array}$ & $t_{\text {PHHR }}(\mathrm{s})$ & AMLR $\left(\mathrm{g} / \mathrm{s} \mathrm{m}^{2}\right)$ & $t_{\text {ign }}(\mathrm{s})$ \\
\hline PMMA & $1034 \pm 50(\mathrm{NA})$ & $87 \pm 4.2$ & $33.3 \pm 1.3$ & $9 \pm 2.2$ \\
PMMA $1 \%$ ZnAl & $960 \pm 34(7)$ & $76 \pm 6.1$ & $30.2 \pm 0.5$ & $9 \pm 2.6$ \\
PMMA/3\% ZnAl & $885 \pm 45(14)$ & $79 \pm 4.1$ & $29.9 \pm 1.2$ & $8 \pm 0.4$ \\
PMMA/5\% ZnAl & $872 \pm 0(16)$ & $77 \pm 0.2$ & $29.5 \pm 0.1$ & $8 \pm 0.3$ \\
PMMA10\% ZnAl & $743 \pm 46(28)$ & $71 \pm 2.2$ & $24.8 \pm 1.5$ & $7 \pm 1.5$ \\
PEBuA & $1761 \pm 85(\mathrm{NA})$ & $122 \pm 16$ & $28.9 \pm 1.2$ & $31 \pm 1.8$ \\
PEBuA1\% ZnAl & $1538 \pm 27(13)$ & $119 \pm 22$ & $26.7 \pm 1.2$ & $28 \pm 5.1$ \\
PEBuA/3\% ZnAl & $1548 \pm 12(12)$ & $103 \pm 4.2$ & $26.3 \pm 0.6$ & $29 \pm 3.5$ \\
PEBuA/5\% ZnAl & $1797 \pm 175(0)$ & $113 \pm 10$ & $28.0 \pm 1.1$ & $21 \pm 1.4$ \\
PEBuA10\% ZnAl & $1729 \pm 36(2)$ & $120 \pm 2.1$ & $27.3 \pm 0.2$ & $20 \pm 0.1$ \\
PE & $2089 \pm 87(\mathrm{NA})$ & $126 \pm 7.7$ & $33.3 \pm 1.3$ & $34 \pm 1.8$ \\
PE/1\% ZnAl & $2038 \pm 66(2)$ & $124 \pm 4.9$ & $32.3 \pm 0.2$ & $33 \pm 2.7$ \\
PE/3\% ZnAl & $1822 \pm 95(13)$ & $119 \pm 1.1$ & $30.1 \pm 1.6$ & $32 \pm 1.7$ \\
PE/5\% ZnAl & $1452 \pm 75(31)$ & $123 \pm 9.9$ & $25.6 \pm 0.2$ & $23 \pm 1.6$ \\
PE/10\% ZnAl & $868 \pm 59(58)$ & $76 \pm 0.8$ & $17.1 \pm 0.8$ & $20 \pm 0.4$ \\
\hline
\end{tabular}

Note: PHRR, peak heat release rate; AMLR, average mass loss rate; tign, time-toignition.

Polymer, Vol. 50, No. 15 (July 2009): pg. 3564-3574. DOI. This article is @ Elsevier and permission has been granted for this version to appear in e-Publications@Marquette. Elsevier does not grant permission for this article to be further copied/distributed or hosted elsewhere without the express permission from Elsevier. 
NOT THE PUBLISHED VERSION; this is the author's final, peer-reviewed manuscript. The published version may be accessed by following the link in the citation at the bottom of the page.

Table 3: Cone summary data of MgAl with PMMA, PEBuA and PE at $50 \mathrm{~kW} / \mathrm{m}^{2}$

\begin{tabular}{lllll}
\hline Formulation & $\begin{array}{l}\text { PHRR }\left(\mathrm{kW} / \mathrm{m}^{2}\right)(\% \\
\text { reduction) }\end{array}$ & $t_{\text {PHHR }}(\mathrm{s})$ & AMLR $\left(\mathrm{g} / \mathrm{s} \mathrm{m}^{2}\right)$ & $t_{\text {ign }}(\mathrm{s})$ \\
\hline PMMA & $1179 \pm 40(\mathrm{NA})$ & $79 \pm 9.1$ & $35.9 \pm 2.2$ & $13 \pm 1.5$ \\
PMMA $10 \% \mathrm{MgAl}$ & $608 \pm 36(48)$ & $61 \pm 6.7$ & $16.0 \pm 1.4$ & $15 \pm 1.3$ \\
PEBuA & $2059 \pm 215(\mathrm{NA})$ & $109 \pm 3.5$ & $30.8 \pm 1.6$ & $30 \pm 1.9$ \\
PEBuA $10 \%$ MgAl & $1666 \pm 113(19)$ & $115 \pm 9.9$ & $28.1 \pm 0.2$ & $24 \pm 2.0$ \\
PE & $2585 \pm 226(\mathrm{NA})$ & $104 \pm 6.1$ & $35.1 \pm 1.5$ & $33 \pm 3.2$ \\
PE/10\% MgAl & $1831 \pm 115(29)$ & $122 \pm 2.0$ & $26.7 \pm 0.9$ & $22 \pm 3.3$ \\
\hline
\end{tabular}

Note: PHRR, peak heat release rate; AMLR, average mass loss rate; tign, time-toignition

Table 4: FIGRA and FPI of ZnAl/PE and MgAl/PMMA systems

\begin{tabular}{llllll}
\hline Material & PHRR $\left(\mathrm{kW} / \mathrm{m}^{2}\right)$ & $t_{\text {PHRR }}(\mathrm{s})$ & $t_{\text {ign }}(\mathrm{s})$ & $\begin{array}{l}\text { FIGRA } \\
\left(\mathrm{kW} / \mathrm{m}^{2} / \mathrm{s}\right)\end{array}$ & $\begin{array}{l}\text { FPI x } 1000 \\
\left(\mathrm{~s} / \mathrm{kW} / \mathrm{m}^{2}\right)\end{array}$ \\
\hline PMMA & 1179 & 79 & 13 & 15 & 11 \\
PMMA $10 \%$ & 608 & 61 & 15 & 10 & 24 \\
MgAl & & 71 & 7 & 11 & 9 \\
PMMA $10 \%$ & 743 & & & & \\
ZnAl & & 126 & 34 & 17 & 16 \\
PE & 2089 & 122 & 22 & 15 & 12 \\
PE/10\% MgAl & 1831 & 76 & 20 & 11 & 23 \\
PE/10\% ZnAl & 868 & & & & \\
\hline
\end{tabular}

Table 5: Evaluation of mechanical properties

\begin{tabular}{lll}
\hline Material & Tensile strength $(\sigma)(\mathrm{MPa})$ & Elongation at break $(\%)$ \\
\hline PEBUA & 12.0 & 816 \\
PEBUA/5\% ZnAl & 11.7 & 812 \\
PEBUA $10 \%$ ZnAl & 11.0 & 776 \\
PEBUA/10\% MgAl & 10.4 & 758 \\
PE & 10.1 & 402 \\
PE/5\% ZnAl & 9.8 & 505 \\
PE/10\% ZnAl & 9.6 & 512 \\
PE/10\% MgAl & 8.5 & 84 \\
PMMA & 36.9 & 5 \\
PMMA $/ 5 \%$ ZnAl & 33.4 & 4 \\
PMMA $10 \%$ MgAl & 36.1 & 3 \\
\hline
\end{tabular}

Polymer, Vol. 50, No. 15 (July 2009): pg. 3564-3574. DOI. This article is (C Elsevier and permission has been granted for this version to appear in e-Publications@Marquette. Elsevier does not grant permission for this article to be further copied/distributed or hosted elsewhere without the express permission from Elsevier. 
NOT THE PUBLISHED VERSION; this is the author's final, peer-reviewed manuscript. The published version may be accessed by following the link in the citation at the bottom of the page.

Table 6: Tensile tests. Metal hydroxides with PE

\begin{tabular}{llll}
\hline Metal hydroxides & Simulated LDH loading & Tensile strength (MPa) & Elongation at break (\%) \\
\hline $\mathrm{Zn}(\mathrm{OH})_{2}+\mathrm{Al}(\mathrm{OH})_{3}$ & $5 \% \mathrm{ZnAl}$ & 4.7 & 168 \\
$\mathrm{Zn}(\mathrm{OH})_{2}+\mathrm{Al}(\mathrm{OH})_{3}$ & $10 \% \mathrm{ZnAl}$ & 7.2 & 117 \\
$\mathrm{Zn}(\mathrm{OH})_{2}+\mathrm{Al}(\mathrm{OH})_{3}$ & & 5.9 & 99 \\
$\mathrm{Mg}(\mathrm{OH})_{2}+\mathrm{Al}(\mathrm{OH})_{3}$ & $5 \% \mathrm{MgAl}$ & 7.9 & 251 \\
$\mathrm{Mg}(\mathrm{OH})_{2}+\mathrm{Al}(\mathrm{OH})_{3}$ & $10 \% \mathrm{MgAl}$ & 7.1 & 150 \\
$\mathrm{Mg}(\mathrm{OH})_{2}+\mathrm{Al}(\mathrm{OH})_{3}$ & & 7.4 & 278 \\
\hline
\end{tabular}

Note: The quantities and ratios of the metal hydroxides used in each sample was calculated based on elemental analysis of the LDHs and the particular loading targeted.

a In this sample, the metal hydroxides are combined to make a $10 \%$ loading (wt. \%) in PE.

Table 7: Cone calorimetric results for metal hydroxides with PE

\begin{tabular}{lllllll}
\hline Formulation & $\begin{array}{l}\text { Simulated } \\
\text { formulation }\end{array}$ & $\begin{array}{l}\text { PHRR }\left(\mathrm{kW} / \mathrm{m}^{2}\right)[\% \\
\text { reduction] }\end{array}$ & $t_{\text {PHRR }}(\mathrm{s})$ & THR & AMLR $\left(\mathrm{g} / \mathrm{s} \mathrm{\textrm {m } ^ { 2 } )}\right.$ & $t_{\text {ign }}(\mathrm{s})$ \\
\hline Control sample & $\mathrm{PE}$ & $2111 \pm 171[\mathrm{NA}]$ & $111 \pm 7.0$ & $138 \pm 2$ & $29.1 \pm 0.5$ & $38 \pm 1.7$ \\
$\mathrm{Zn}(\mathrm{OH})_{2}+\mathrm{Al}(\mathrm{OH})_{3}$ & $\mathrm{PE} / 5 \% \mathrm{ZnAl}$ & $1716 \pm 96[19]$ & $112 \pm 1.1$ & $129 \pm 2$ & $23.6 \pm 1.6$ & $33 \pm 0.2$ \\
$\mathrm{Zn}(\mathrm{OH})_{2}+\mathrm{Al}(\mathrm{OH})_{3}$ & $\mathrm{PE} / 10 \% \mathrm{ZnAl}$ & $1886 \pm 63[11]$ & $113 \pm 3.5$ & $134 \pm 0$ & $23.7 \pm 0.0$ & $27 \pm 0.3$ \\
$\mathrm{Zn}(\mathrm{OH})_{2}+\mathrm{Al}(\mathrm{OH})_{3}$ & & $1899 \pm 108[10]$ & $115 \pm 16.0$ & $128 \pm 3$ & $21.3 \pm 3.6$ & $18 \pm 3.2$ \\
$\mathrm{Mg}(\mathrm{OH})_{2}+\mathrm{Al}(\mathrm{OH})_{3}$ & $\mathrm{PE} / 5 \% \mathrm{MgAl}$ & $1801 \pm 121[15]$ & $119 \pm 4.5$ & $141 \pm 1$ & $28.4 \pm 2.4$ & $33 \pm 2.3$ \\
$\mathrm{Mg}(\mathrm{OH})_{2}+\mathrm{Al}(\mathrm{OH})_{3}$ & PE $/ 10 \% \mathrm{MgAl}$ & $1819 \pm 68[14]$ & $116 \pm 3.3$ & $132 \pm 0$ & $13.3 \pm 1.2$ & $34 \pm 2.6$ \\
$\mathrm{Mg}(\mathrm{OH})_{2}+\mathrm{Al}(\mathrm{OH})_{3}$ & & $1358 \pm 55[36]$ & $115 \pm 6.2$ & $130 \pm 0$ & $22.2 \pm 0.2$ & $29 \pm 0.2$ \\
\hline
\end{tabular}

Polymer, Vol. 50, No. 15 (July 2009): pg. 3564-3574. DOI. This article is (C Elsevier and permission has been granted for this version to appear in e-Publications@Marquette. Elsevier does not grant permission for this article to be further copied/distributed or hosted elsewhere without the express permission from Elsevier. 
NOT THE PUBLISHED VERSION; this is the author's final, peer-reviewed manuscript. The published version may be accessed by following the link in the citation at the bottom of the page.

Figure 1
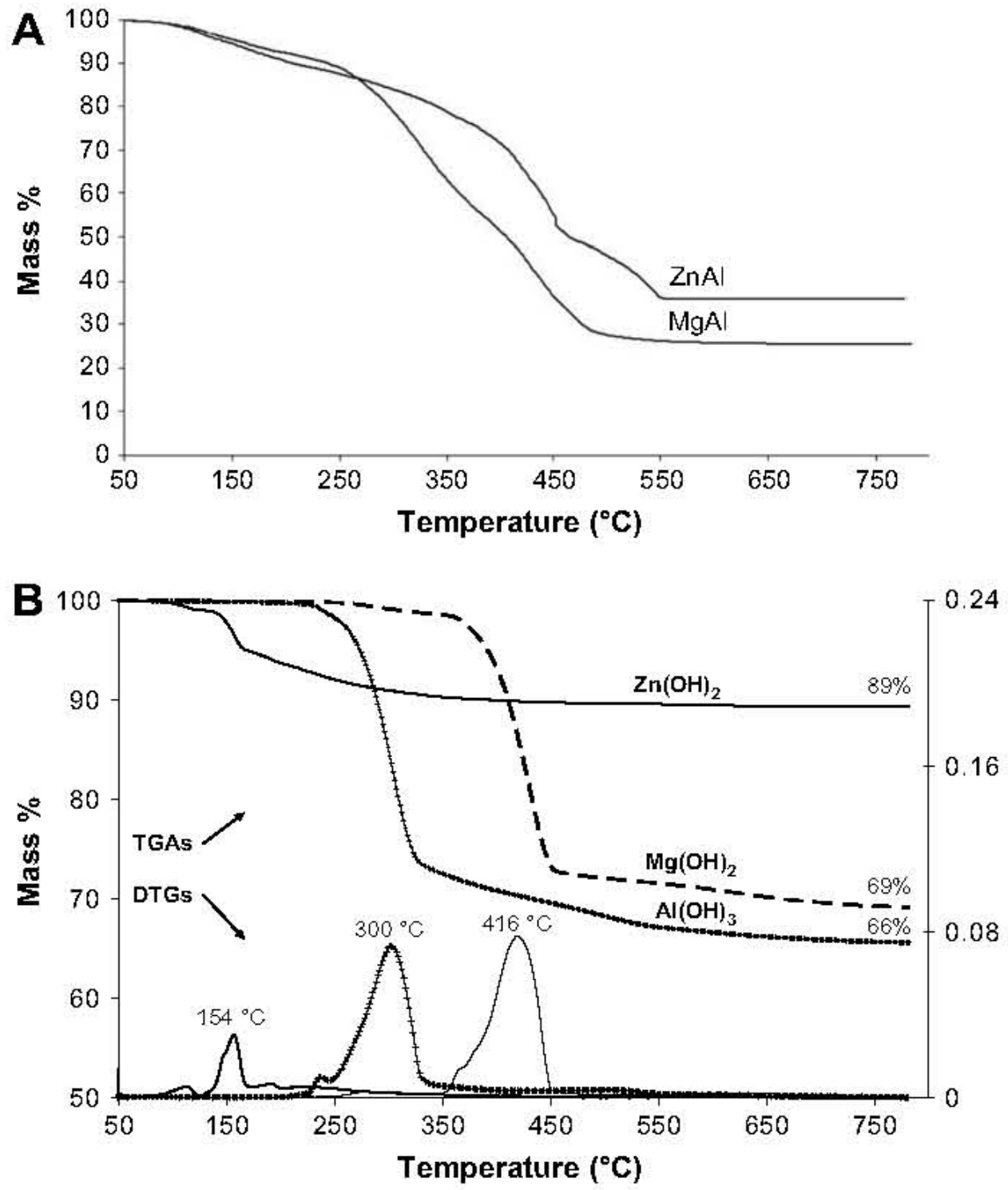

(A) TGA curves of zinc aluminum oleate LDH ( $\mathrm{ZnAl}$ ) and magnesium aluminum oleate LDH (MgAl). (B) TGA curves of selected metal hydroxides. All TGA experiments were performed in an air environment, at $20^{\circ} \mathrm{C} / \mathrm{min}$, from 50 to $800^{\circ} \mathrm{C}$.

Polymer, Vol. 50, No. 15 (July 2009): pg. 3564-3574. DOI. This article is (C Elsevier and permission has been granted for this version to appear in e-Publications@Marquette. Elsevier does not grant permission for this article to be further copied/distributed or hosted elsewhere without the express permission from Elsevier. 
NOT THE PUBLISHED VERSION; this is the author's final, peer-reviewed manuscript. The published version may be accessed by following the link in the citation at the bottom of the page.

\section{Figure 2}

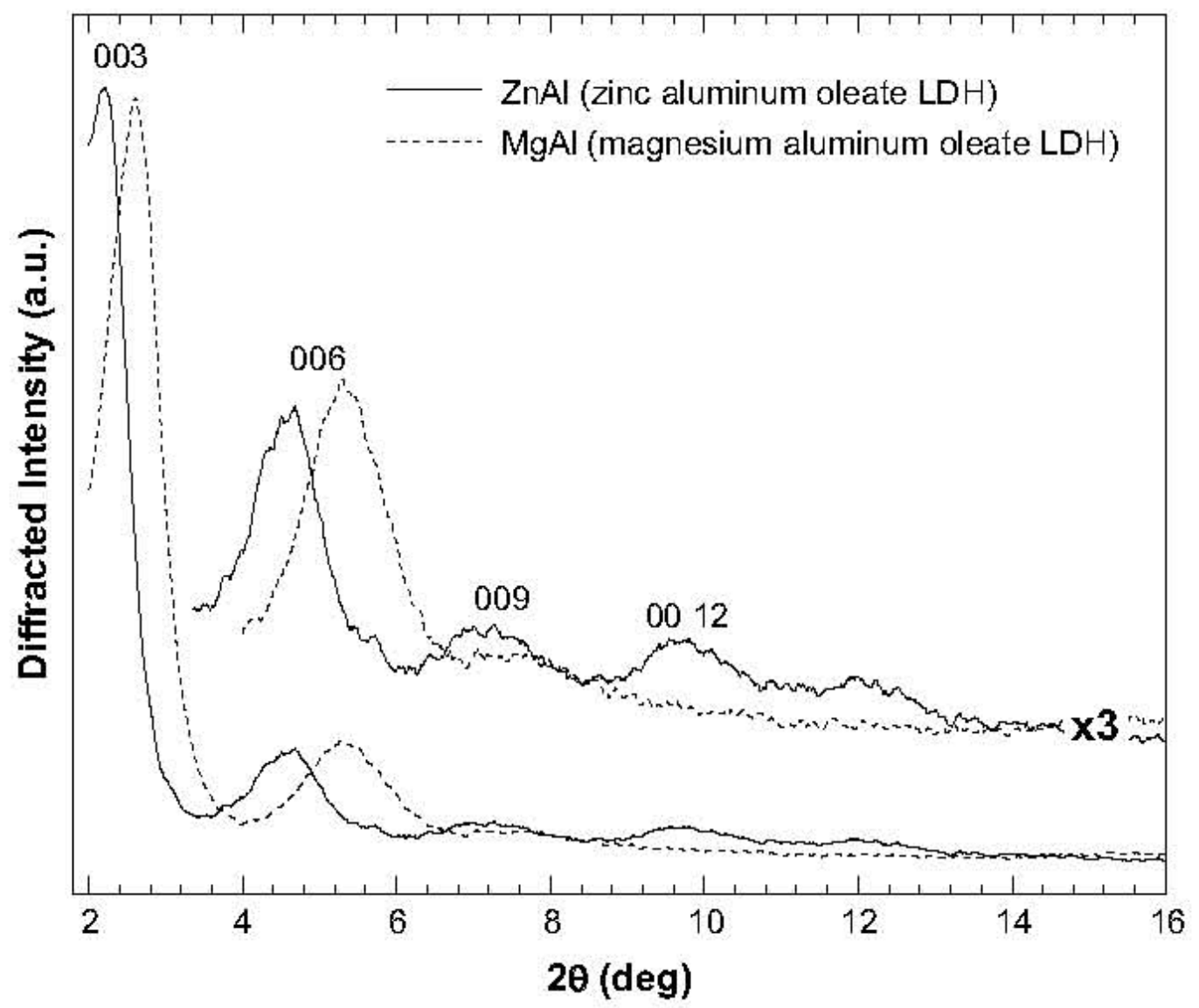

X-ray diffraction traces of $\mathrm{ZnAl}$ and MgAl. The top traces are the same data at $3 \times$ intensity to highlight the higher order Bragg reflections, where observable.

\section{Figure 3}
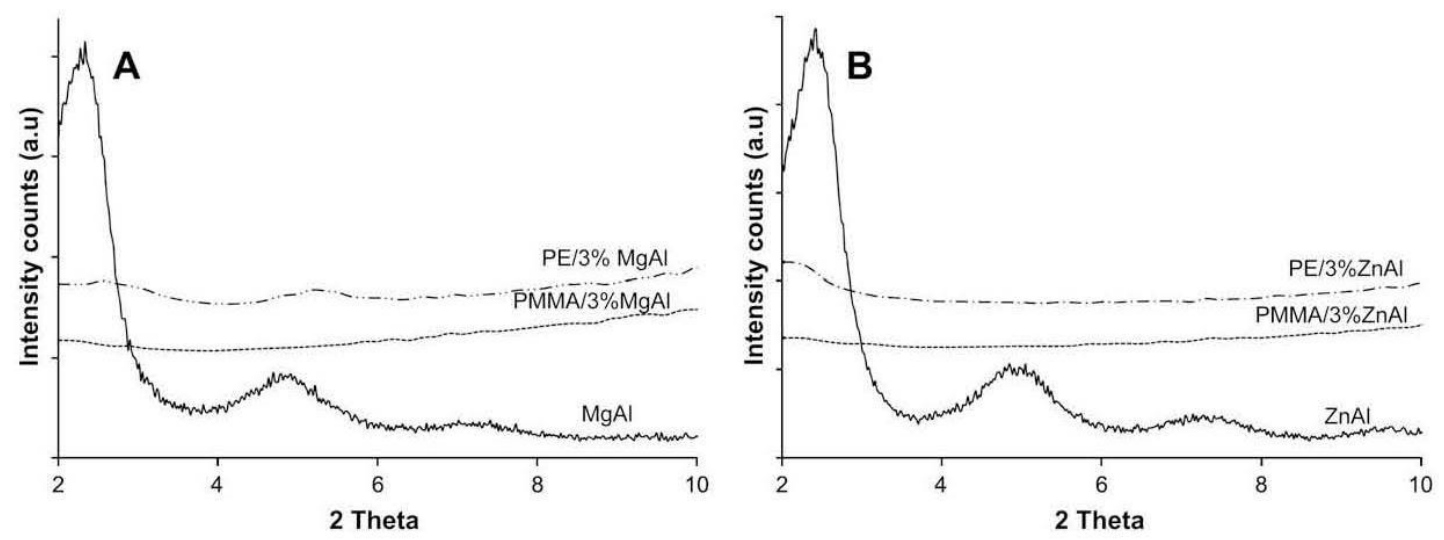

Polymer, Vol. 50, No. 15 (July 2009): pg. 3564-3574. DOI. This article is (C Elsevier and permission has been granted for this version to appear in e-Publications@Marquette. Elsevier does not grant permission for this article to be further copied/distributed or hosted elsewhere without the express permission from Elsevier. 
NOT THE PUBLISHED VERSION; this is the author's final, peer-reviewed manuscript. The published version may be accessed by following the link in the citation at the bottom of the page.

XRD traces of (A) MgAl and its PE and PMMA composites and (B) ZnAl and its PE and PMMA composites. Note: the composites are scaled-up $(5 \times)$ in intensity compared to the organo-LDHs.

\section{Figure 4}
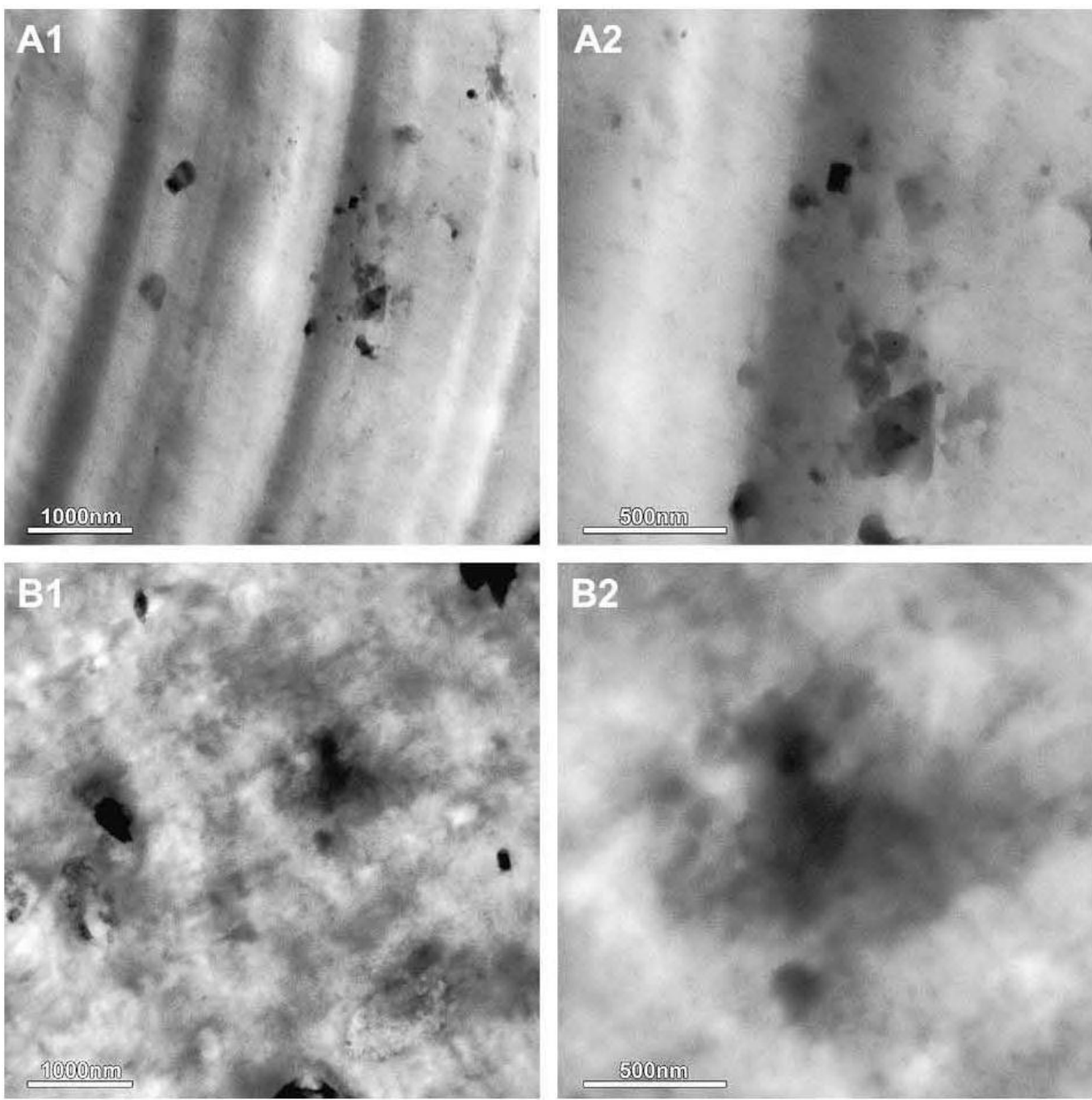

Bright field TEM images of PE/MgAl oleate LDH (A1, A2) and PE/ZnAl oleate LDH (B1, B2) at different magnifications.

Polymer, Vol. 50, No. 15 (July 2009): pg. 3564-3574. DOI. This article is (C) Elsevier and permission has been granted for this version to appear in e-Publications@Marquette. Elsevier does not grant permission for this article to be further copied/distributed or hosted elsewhere without the express permission from Elsevier. 
NOT THE PUBLISHED VERSION; this is the author's final, peer-reviewed manuscript. The published version may be accessed by following the link in the citation at the bottom of the page.

\section{Figure 5}
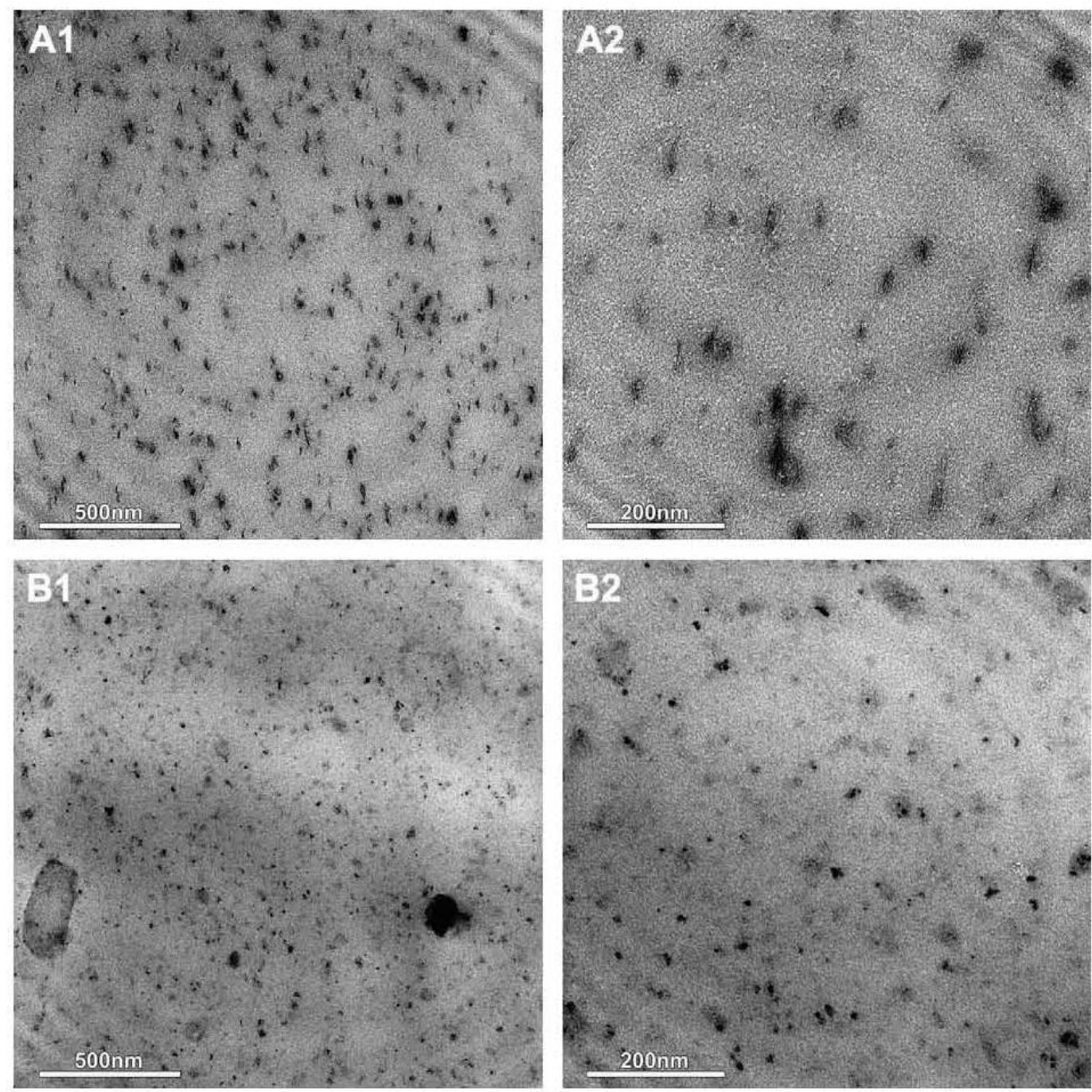

TEM images of PMMA/3\% MgAl oleate LDH $(\mathrm{A} 1, \mathrm{~A} 2)$ and PMMA $/ 3 \% \mathrm{ZnAl}$ oleate LDH (B1, B2) at different magnifications.

Polymer, Vol. 50, No. 15 (July 2009): pg. 3564-3574. DOI. This article is (C Elsevier and permission has been granted for this version to appear in e-Publications@Marquette. Elsevier does not grant permission for this article to be further copied/distributed or hosted elsewhere without the express permission from Elsevier. 
NOT THE PUBLISHED VERSION; this is the author's final, peer-reviewed manuscript. The published version may be accessed by following the link in the citation at the bottom of the page.

\section{Figure 6}

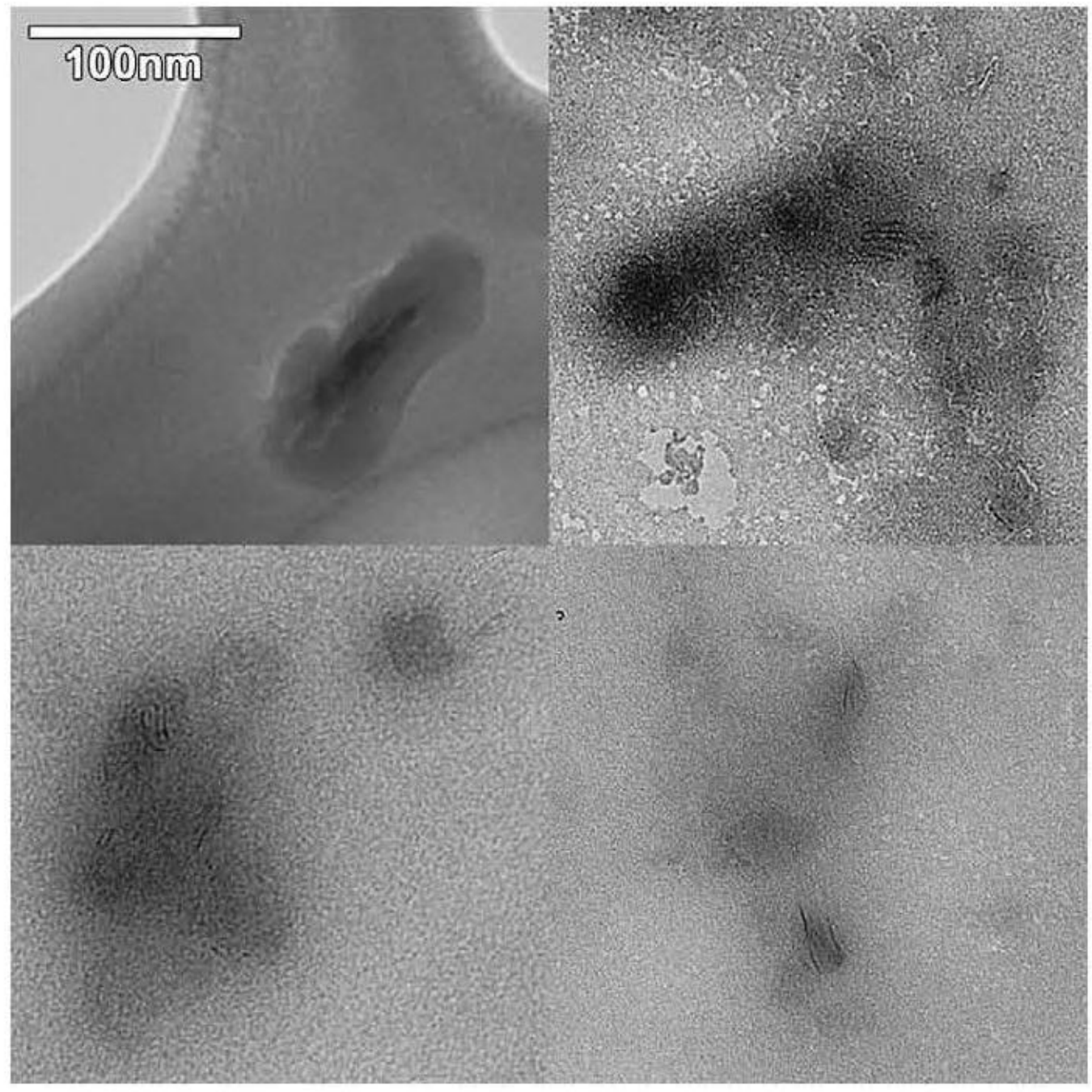

TEM images of MgAl extracted from PMMA/3\% MgAl with acetone.

Polymer, Vol. 50, No. 15 (July 2009): pg. 3564-3574. DOI. This article is (C Elsevier and permission has been granted for this version to appear in e-Publications@Marquette. Elsevier does not grant permission for this article to be further copied/distributed or hosted elsewhere without the express permission from Elsevier. 


\section{Figure 7}

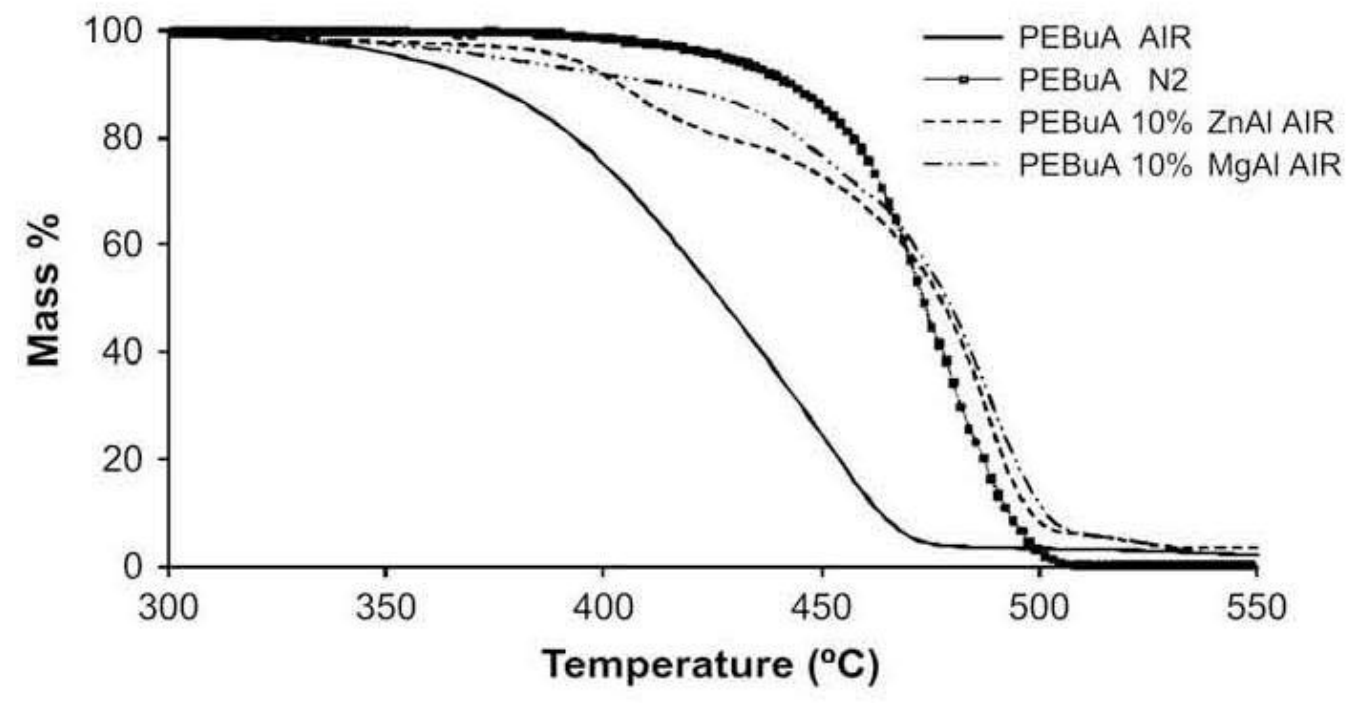

TGA curves of PEBuA/ZnAl and PEBuA/MgAl composites at $20^{\circ} \mathrm{C} / \mathrm{min}$.

\section{Figure 8}

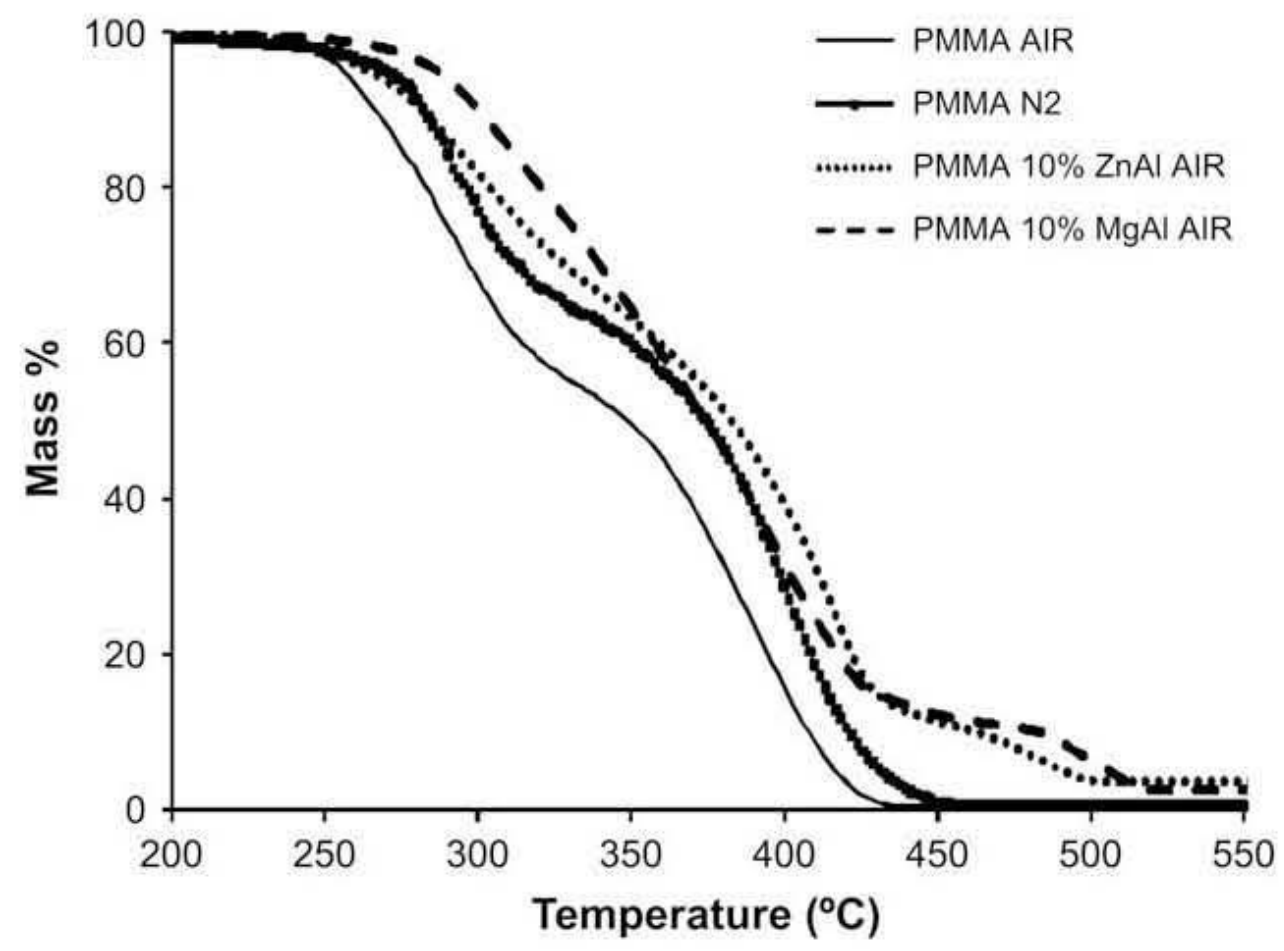

TGA curves of PMMA/ZnAl and PMMA/MgAl composites at $20^{\circ} \mathrm{C} / \mathrm{min}$.

Polymer, Vol. 50, No. 15 (July 2009): pg. 3564-3574. DOI. This article is @ Elsevier and permission has been granted for this version to appear in e-Publications@Marquette. Elsevier does not grant permission for this article to be further copied/distributed or hosted elsewhere without the express permission from Elsevier. 
NOT THE PUBLISHED VERSION; this is the author's final, peer-reviewed manuscript. The published version may be accessed by following the link in the citation at the bottom of the page.

Figure 9

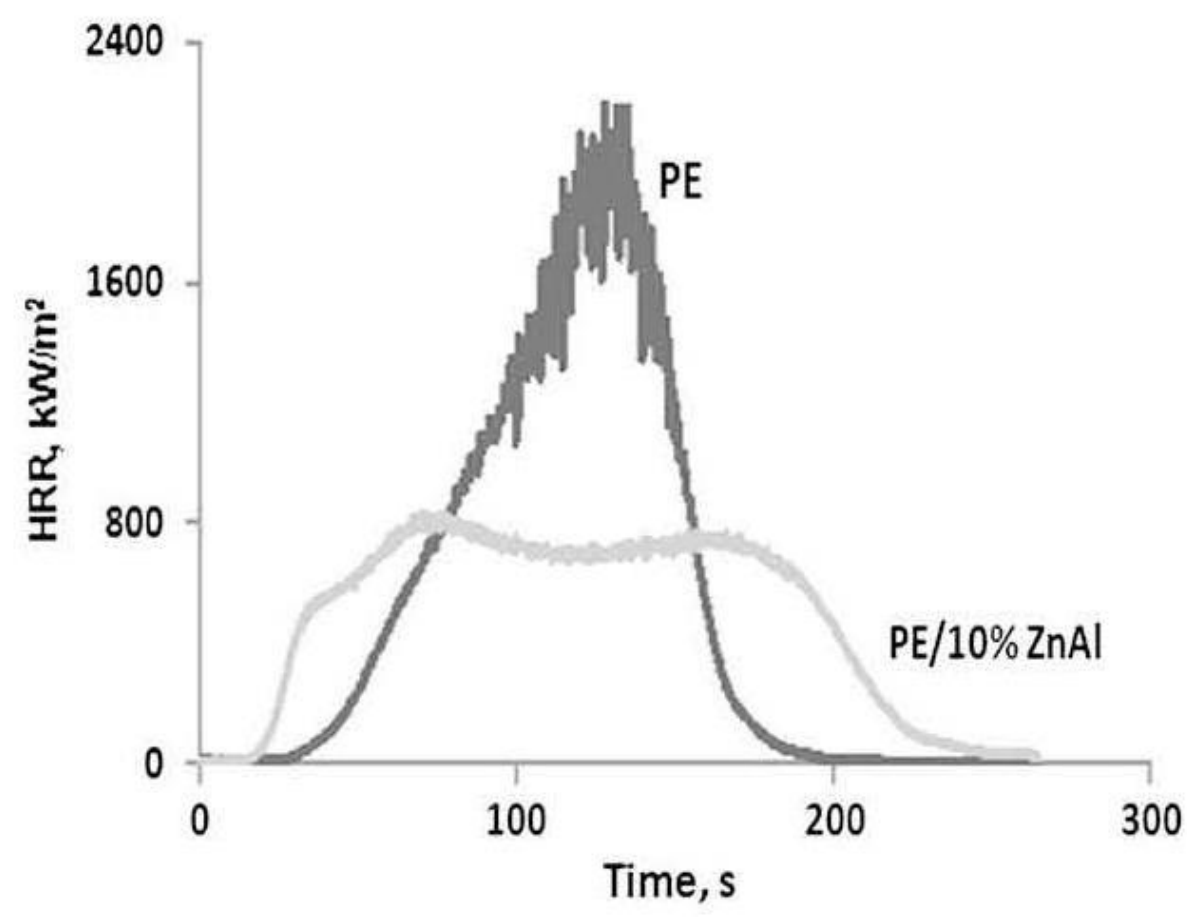

HRR plots of virgin PE and $\mathrm{PE} / 10 \% \mathrm{ZnAl}$ at $50 \mathrm{~kW} / \mathrm{m}^{2}$.

\section{Figure 10}

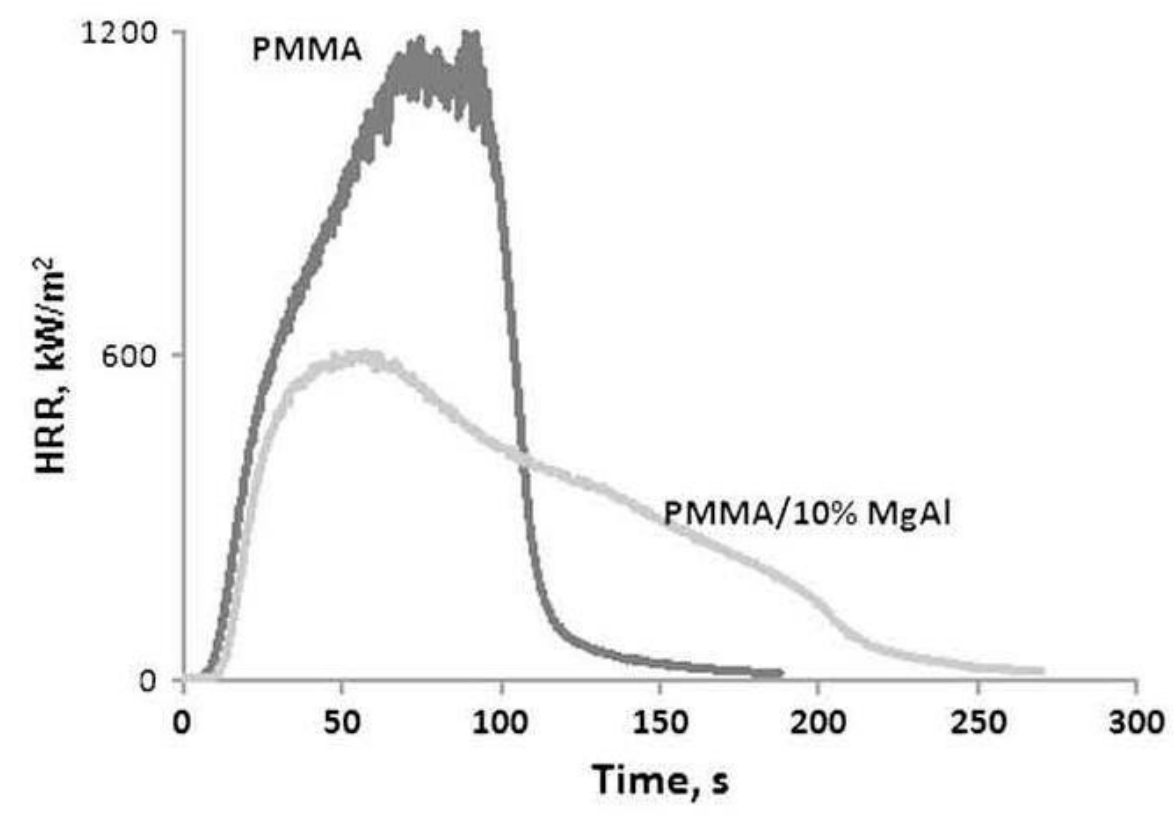

HRR plots of virgin PMMA and PMMA $/ 10 \% \mathrm{MgAl}$ at $50 \mathrm{~kW} / \mathrm{m}^{2}$.

Polymer, Vol. 50, No. 15 (July 2009): pg. 3564-3574. DOI. This article is @ Elsevier and permission has been granted for this version to appear in e-Publications@Marquette. Elsevier does not grant permission for this article to be further copied/distributed or hosted elsewhere without the express permission from Elsevier. 
NOT THE PUBLISHED VERSION; this is the author's final, peer-reviewed manuscript. The published version may be accessed by following the link in the citation at the bottom of the page.

Figure 11
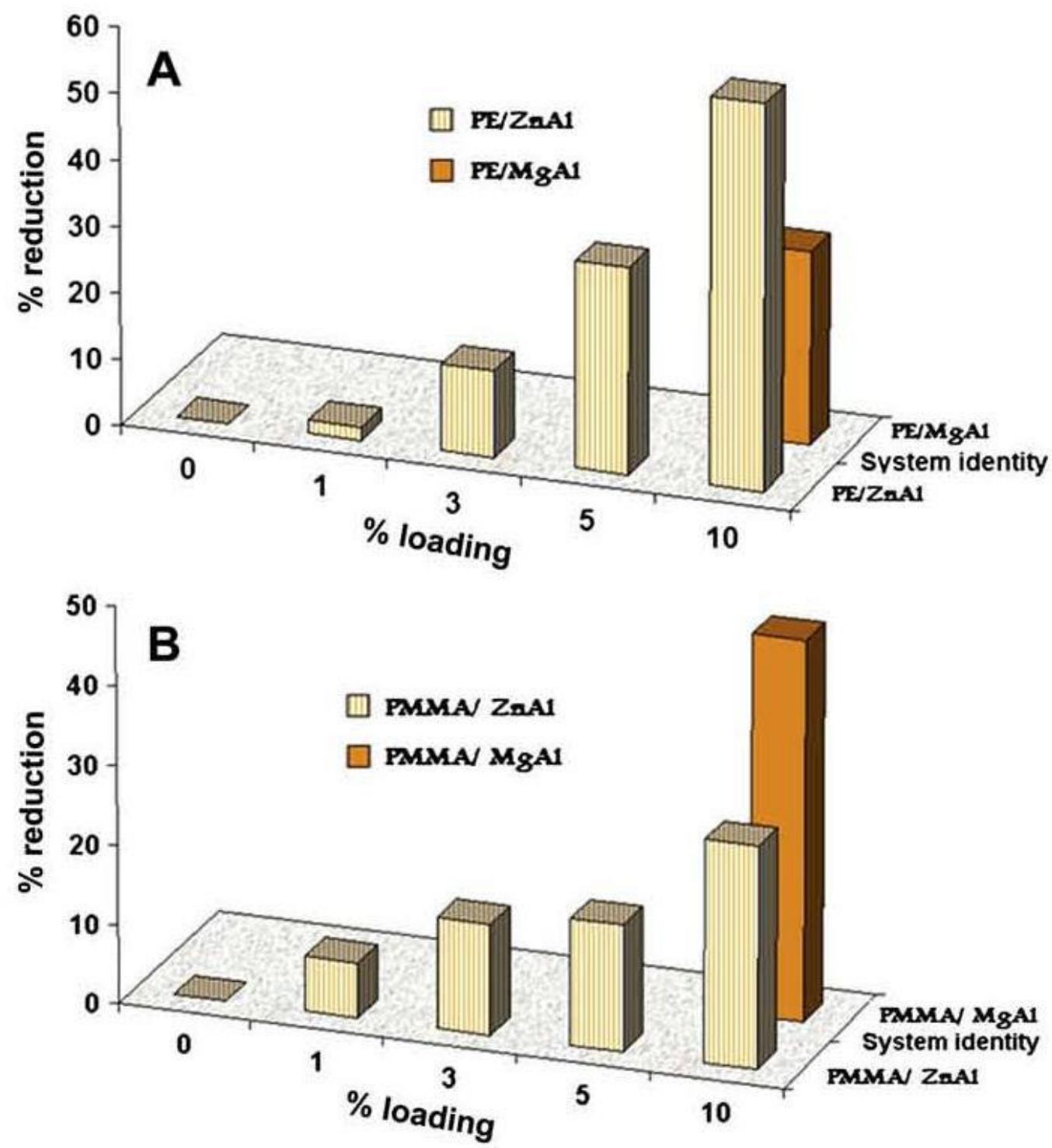

Comparison of the fire properties of polymeric systems of $\mathrm{ZnAl}$ and MgAl. The \% reduction in PHRR is plotted vs. the LDH loading (wt.\%) and the cone heat flux was set to $50 \mathrm{~kW} / \mathrm{m}^{2}$. (A) PE systems; (B) PMMA systems.

Polymer, Vol. 50, No. 15 (July 2009): pg. 3564-3574. DOI. This article is @ Elsevier and permission has been granted for this version to appear in e-Publications@Marquette. Elsevier does not grant permission for this article to be further copied/distributed or hosted elsewhere without the express permission from Elsevier. 
NOT THE PUBLISHED VERSION; this is the author's final, peer-reviewed manuscript. The published version may be accessed by following the link in the citation at the bottom of the page.

\section{Figure 12}

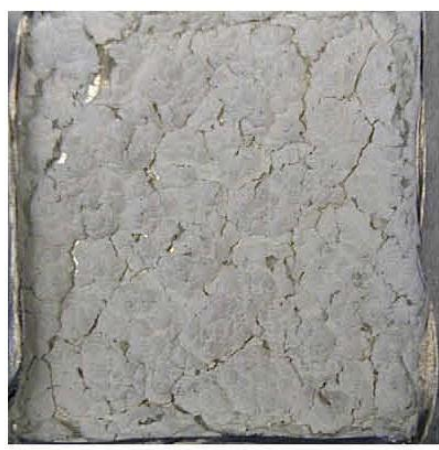

PE/ $10 \% \mathrm{ZnA}$

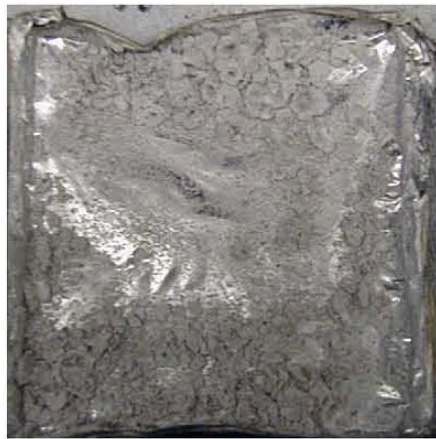

PE/ $10 \% \mathrm{MgAl}$

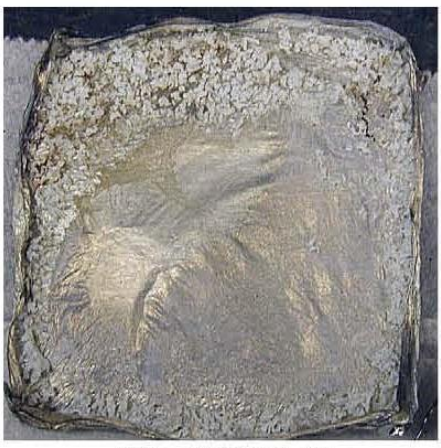

PEBuAl 10\% ZnAl

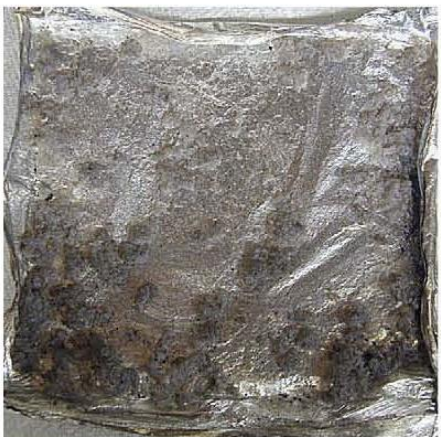

PEBuA/ $10 \% \mathrm{MgAl}$

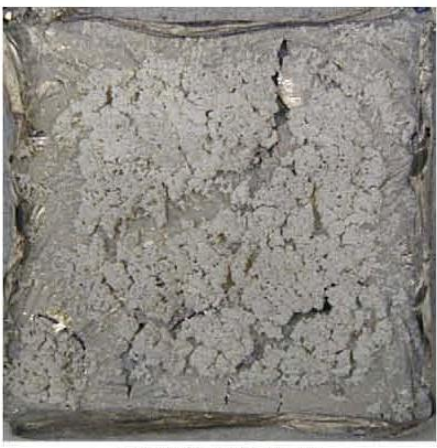

PMMA/ $10 \%$ ZnAl

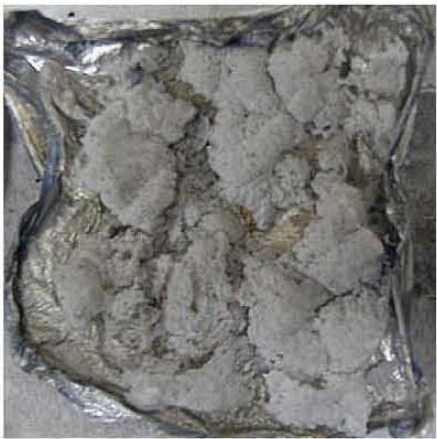

PMMA/ $10 \%$ MgAl

Cone char of ZnAl and MgAl based composites with different polymers (heat flux 50 $\mathrm{kW} / \mathrm{m}^{2}$ )

Polymer, Vol. 50, No. 15 (July 2009): pg. 3564-3574. DOI. This article is @ Elsevier and permission has been granted for this version to appear in e-Publications@Marquette. Elsevier does not grant permission for this article to be further copied/distributed or hosted elsewhere without the express permission from Elsevier. 